\title{
Paisajes y figuras del clero de una ciudad levítica: la primada Toledo en la Época Moderna ${ }^{1}$
}

\author{
Francisco José Aranda Pérez²
}

Recibido: 11 de agosto de 2021 / Aceptado: 13 de octubre de 2021

Resumen. El estamento clerical en la Toledo de la Edad Moderna no sólo es arquetípico sino también especial, por su inusitada fuerza y por la huella que ha dejado hasta el día de hoy en la propia ciudad. Se analiza y se propone una omnicompresión del fenómeno eclesiástico en la capital espiritual de España que abarca tanto el estudio de un paisaje urbano característico, procedente de descripciones reales y mitificadas; un análisis de los distintos niveles clericales y sus relaciones internas; y una serie de consideraciones sobre las diferentes interactuaciones del clero con el resto de la población y los poderes cívicos.

Palabras clave: Clero, Clero Secular, Clero Regular, Arzobispos, Cabildos, Curas, Parroquias, Toledo, Historiografía, Edad Moderna, Primacía.

\section{[en] Landscapes and Figures of the Clergy of a Levitical City: the primada Toledo in the Early Modern Age}

\begin{abstract}
The clerical establishment in Toledo in the Early Modern Age is not only archetypal but also special, for its unusual strength and for the mark it has left on the city itself to nowadays. An omnicompression of the ecclesiastical phenomenon in the spiritual capital of Spain is analyzed and proposed, which includes both the study of a characteristic urban landscape, derived from real and mythologized descriptions; an analysis of the different clerical levels and their internal relationships; and a series of considerations on the different interactions of the clergy with the rest of the population and the civic powers.
\end{abstract}

Keywords: Clergy, Secular Clergy, Regular Clergy, Archbishops, Cabildos, Priests, Parishes, Toledo, Historiography, Early Modern Age, Primacy.

Sumario: Una cristianópolis a la vista. Un complejo y jerárquico organigrama clericalopolitano. Intersecciones del clero. Bibliografía.

1 Proyecto Regional de Investigación Cientifica y Transferencia de Tecnología, Junta de Comunidades de Casti1la-La Mancha-Fondos de Desarrollo Europeo (FEDER) “CLAUSTRAT. El Patrimonio Material e Inmaterial de los Conventos de Toledo y su diócesis: Evolución, Actualidad y Perspectivas preocupantes (referencia SBPLY/19/180501/000096), 2020-2022. También Proyecto Universitario de Investigación-Grupo de Investigación Consolidado en la UCLM "De Re Hispanica” (Sobre lo hispánico, DEREHIS), (2021-GRIN-31050). Dedicado a la entrañable memoria de la última abadesa de las capuchinas de Toledo, madre Pilar Pinés Lampaya, que santa gloria haya.

2 Departamento de Historia, Facultad de Humanidades y Patrimonio (Toledo). Universidad de Castilla-La Mancha.

Researcher ID: R-9459-2018; Ciência ID: 8C13-73D2-AF90; https://orcid.org/0000-0002-8409-3683

E-mail: FcoJose.Aranda@uclm.es 
Como citar: Aranda Pérez, F. J. (2021). Paisajes y figuras del clero de una ciudad levítica: la primada Toledo en la Época Moderna, en Cuadernos de Historia Moderna, 567-611.

Urbs, et Roma hispanica... ${ }^{3}$

"La Imperial Toledo, Ciudad ilustre, dignísima cabeza metrópoli de su reino y Nueva Castilla, patria y sepultura de muchas reales personas, famosa entre las más ínclitas, generosas y opulentas de España"4

\section{Una cristianópolis a la vista}

Toledo fue la más levítica de las ciudades hispanas; la Roma de la Monarquía Católica, según reza la cita inicial... De hecho, su aspecto o skyline urbanita lo pregonaba, e, ítem más, en su entramado social las huestes clericales le otorgaban una especial nota de distinción, con un difícilmente parangonable arzobispo -casi siempre un príncipe-cardenal de la Santa Iglesia- a la cabeza. Era esta una característica y una vocación sacra que venía de lejos, desde aquella época gótica en la que en la ciudad, que era caput del Reino Visigodo de Toledo, se reunían los Concilios que venían a conformar el orden político y eclesiástico de aquel primer reino oficialmente católico desde Flavio Recaredo (586-589-601) ${ }^{5}$. De la entronización de reyes y de la reunión de concilios bajo la autoridad de la sede archidiocesana toledana se formará una tradición gótica que sobrevolará esta historia hasta los tiempos contemporáneos. Tras un largo interregno islámico, después de la llamada reconquista cristiana de 1085, se hibridó la supervivencia de la peculiar mozarabía con la pujanza reformista-romana-cluniacense de un Bernard de Sédirac (1086$1124)^{6}$, quien pronto, arrancando grandes concesiones de la corona castellana y apoyado en las consignas del Dictatus Papae de Gregorio VII (1073-1085), enfiló a la iglesia toledana al título más que honorífico de Primada de las Españas, ante el beato papa Urbano II (1088-1099, el de la primera Cruzada ${ }^{7}$ ), en disputa, por descontado, con otras sedes hispánicas ${ }^{8}$. Dicha primacía no sólo supuso ventajas

3 Herrera Vaca, F. de: Urbs, et Roma hispanica sive praeexcellentia, et magnitudine Toletanae urbis cum magnitudine, et praexcellentia urbis Romanae conferanda, Toledo, Franciscus Calvo, 1664.

$4 \quad$ Lozano Parreño y Navarro, A.: Compendio histórico-cronológico-geográfico en que se explica el número de dignidades, canonicatos, raciones, medias raciones y beneficios de todas las iglesias metropolitanas y catedrales de España..., Madrid, Antonio Pérez de Soto, 1756, p. 1.

5 Que recogía históricamente el guante del imperio cristiano-niceno de Teodosio I el Grande (379-395) o del posterior Imperio Romano Oriental-Bizancio. Precisamente, la recuperación de la Ciudad o Sede de los Concilios es lo que en la actualidad se está dilucidando y debatiendo en la llamada Vega Baja de Toledo. V. V. A. A.: La Vega Baja de Toledo, Toledo, Toletum Visigodo, 2009.

6 Rivera Recio, J. F.: El Arzobispo de Toledo don Bernardo de Cluny (1085-1124), Roma, Iglesia Nacional Española, 1962. Esta primacía se entendía sobre todo en el ámbito judicial canónico.

7 Cunctis sanctorum, bula, Agnani, 15/10/1088.

8 Incluida Braga, que después pasaría a ser la primada portuguesa, amén de Tarragona, Sevilla, Santiago, etc. V. Castejón y Fonseca, D. de: Primacía de la Santa Iglesia de Toledo, su origen, sus medras, sus progresos... defendidas contra las impugnaciones de Braga, Madrid, Diego Díaz de la Carrera, 1645. El tal licenciado Castejón era obispo de Lugo pero gobernador del arzobispado de Toledo por el belicoso Cardenal-Infante don 
en la administración y justicia meramente eclesiásticas sino que otorgó al arzobispo y a su arzobispado una cierta preeminencia en lo político, tanto en lo religioso como en lo civil, y, por ende en lo ideológico y cultural, amén de una interlocución privilegiada con Roma, con el Papa y la Curia.

Pero también, máxime desde los Reyes Católicos y Carlos I, el protagonismo de la monarquía española fue evidente en los discursos políticos y, por ende, historiográficos y artísticos. Había que buscar un encaje con la antigua tradición monárquico-eclesiástica, que se visibilizó con el interés creciente por transformar la antigua ciudad medieval en una ciudad a lo moderno, con empaque renacentista ${ }^{9}$. Cuestión aparte es que esta transformación radical de cara, de alzado más que de planta, devino quizá en toda una ciudad barroca pero por más eclesiástica, en donde se acumuló el goticismo (visigodo), la negación de la cautividad mahometana, la restauración cristiana medieval, el imperialismo decadente de los Austrias (menores), y el esencialismo cristiano, amén de la emulación a la Roma pontificia y la exaltación de la primacía ${ }^{10}$. Aparentemente, y es la sensación que impera todavía hoy, solo la parte eclesiástica de Toledo pudo aguantar incólume el tirón de la Historia.

Por demás, durante toda la Edad Media se forma no sólo una diócesis espectacular, que una vez más rivalizaría con la romana en territorio y recursos ${ }^{11}$, sino que paralelamente se formaría el señorío eclesiástico más importante de la península, señorío que desbordaría el antiguo reino de Toledo (uno de los reinos castellanos centrales, en ambos sentidos ${ }^{12}$ ), y que se dirigiría al compás de la reconquista andaluza hasta los reinos de Jaén y Granada e incluso hacia el Norte de África con la empresa cisneriana de Orán. Comprendía unas 220 poblaciones, entre villas y lugares, entre las que destacan Talavera de la Reina, Alcalá de Henares y el Adelantamiento de Cazorla, con más de 21.000 vecinos-vasallos (unas 80.000 almas, en cifras groseramente redondas) y unos 62.000 kilómetros cuadrados. También era la testa de la vasta provincia eclesiástica sufragánea compuesta por las diócesis de Cartagena, Córdoba, Cuenca, Jaén, Osma, Segovia, Sigüenza, Valladolid y la Abadía de Alcalá la Real de Jaén hasta el siglo XIX ${ }^{13}$. Por supuesto, sería la Santa Iglesia Catedral, refundada su

Fernando de Austria, y había sido con anterioridad canónigo, vicario general, inquisidor y juez apostólico en Toledo aunque solía residir en Madrid. Fue el que le franqueó el paso al alto clero toledano al licenciado Ceballos (Aranda Pérez, F. J.: Jerónimo de Ceballos, op. cit. infra (nota 61), pp. 50-51).

9 A lo romano. Esta imagen de Toledo ha sido tratada profusamente desde las especializadas obras de Marías y de Díez del Corral, v. gr., Marías Franco, F.: La Arquitectura del Renacimiento en Toledo (1541-1631), Toledo-Madrid, CSIC, 1983-86, especialmente tomo I, e infinidad de secuelas, incluida la de El Greco. Biografía de un pintor extravagante, Madrid, Nerea, 1997; Díez del Corral Garnica, R.: Arquitectura y mecenazgo. La imagen de Toledo en el Renacimiento, Madrid, Alianza, 1987.

10 Cfr. Martínez Gil, F.: "De civitas regia a civitas dei. El imaginario histórico de Toledo en los siglos XVI y XVII”, en Vizuete Mendoza, J. C., Martín Sánchez, J. (coords.): Sacra loca toletana. Los espacios sagrados en Toledo, Cuenca, Ediciones de la UCLM, 2008, pp. 319-367; mismo autor: La invención de Toledo. Imágenes históricas de una identidad urbana, Ciudad Real, Almud, 2007.

11 Según Barrio Gozalo, M.: "Rentas de los obispos españoles y pensiones que las gravan en el Antiguo Régimen (1556-1834)", Revista de Historia Moderna, 32, (2014), pp. 219-244, cuadro 3, Toledo, con 2,25 millones de reales a finales del XVI duplicaba en rentas líquidas a Sevilla, cuadruplicaba a Valencia, quintuplicaba a Santiago o Córdoba, sextuplicaba a Zaragoza...

12 Regiones históricas de Extremadura, Castilla la Nueva y Andalucía, que comprendían las actuales provincias de Madrid, Toledo, Ciudad Real, partes de Cáceres, Badajoz, Guadalajara y Albacete y enclaves en Jaén, Granada y Norte de África (Orán).

13 Fernández Collado, Á.: Historia de la Iglesia en España. Edad Moderna, Toledo, Instituto Teológico San Ildefonso, 2007, p. 191 y ss. Desde el Ochocientos serían sufragáneas Coria, Plasencia, Cuenca, Sigüenza y las 
fábrica en 1226 sobre los fundamentos de un templo visigótico y una gran mezquita-aljama suní, con sus propios órganos de gobierno capitular, la que animaría todo este proceso; así como la progresiva creación de arcedianatos y sus correspondientes arciprestazgos que fueron sumando un sin fin de parroquias ${ }^{14}$.

Este emporio eclesiástico secular-diocesano no haría más que agrandarse con la expansión de las órdenes religiosas, monásticas en un primer momento, pero sobre todo mendicantes, especialmente entre los siglos XIII y XVI, con sus sucesivas innovaciones o resurgimientos observantes, que pondrían especialmente en la ciudad de Toledo sus miras de implantación estratégica casi obligada. Conocida es la competitividad que en ese aspecto hubo entre las diferentes órdenes, quienes se solían resistir - junto a instituciones civiles como el Ayuntamiento ${ }^{15}$ - a las nuevas fundaciones, pero que sorteaban esta dificultad estableciéndose en los alrededores de la ciudad para terminar aprovechando cualquier ocasión para incorporarse al interior de las murallas, pretextando falta de salubridad, la ayuda de algún generoso donante, etcétera.

El esplendor eclesiástico de Toledo tenía sus satélites, como el sol sus planetas, y eso se refleja con claridad en el mapa del arzobispado toledano de Portocarrero, en donde, a modo de viñetas ilustrativas, aparecen los lugares de Madrid, Talavera de la Reina (Toledo), Alcaraz (hoy en Albacete), Huéscar (Granada), Orán (Argelia), Ventosilla (Toledo) ${ }^{16}$, Alcalá (actualmente en Madrid) ${ }^{17}$, Ciudad Real, Cazorla (Jaén) y Puente del Arzobispo (Toledo) ${ }^{18}$. Para más abundamiento, había un anillo de palacios, quintas, cigarrales, fincas, palacetes de recreo en entornos semirrurales que pregonaban la gloria mundana de los arzobispos, como el de Buenavista, el cigarral del Ángel Custodio, la quinta de Mirabel, la finca de Ventosilla, o el palacete de Arenas de San Pedro, algunos incluso con sus jardines y cazaderos. No obstante, las primeras residencias eran los Palacios Arzobispales de Toledo, Madrid (definitiva a partir del XVIII) y Alcalá, con el suficiente empaque como para alojar personas reales de paso. A los mismos edificios de asiento, había que añadir ya caducas fortalezas medievales que subsistían malamente, como los castillos y los puentes estratégicos de Almonacid, Brihuega, Canales, Cazorla, Iznatoraf, Iruela (en Jaén), Puente del

nuevas de Madrid-Alcalá y el Priorato de las Órdenes Militares-Ciudad Real, más la de Albacete ya en el siglo XX.

14 Toledo, Calatrava, Guadalajara, Alcaraz, Madrid y Talavera. Todas estas estructuras tenían su clérigo al frente que como veremos solían ser dignidades del arzobispado y del cabildo catedralicio.

15 Archivo Municipal de Toledo, Archivo Secreto, cajón 4, legajo 1, número 20 (Pedraza). Real Cédula de Carlos V, a petición de los procuradores de Cortes, para que la Justicia Real de esta ciudad no permitiese fabricar dentro de ella más casas que las que había para iglesias, hospitales ni monasterios, sin que precediese licencia del prelado que era o por tiempo fuese en esta ciudad. Esta petición es un fijo en muchas reuniones de Cortes, como en 1621, en el siglo XVII en donde la inflación clerical era más que evidente, como denunciaban, entre otros, los escritores arbitristas y reformistas; pero tal reiteración evidencia su incumplimiento...

16 Existe un pequeño fondo sobre esta finca en el Archivo Diocesano de Toledo, sala II, con multitud de detalles de sus reparaciones en la segunda mitad del XVII.

17 Y su universidad mayor, la Complutense. V. por nuestra parte "El influjo complutense, de Cisneros y Fonseca a Carranza", en García Pinilla, I. J. (Coordinador), Disidencia religiosa en Castilla la Nueva en el siglo XVI, Toledo, Almud, 2013, pp. 29-57.

18 Impresionante mapa titulado Toletum Hispanici Orbis Urbs Augusta, Madrid, I. F. Leonardus, 1681, inspirador de los posteriores de Tomás López. También aparecen representados los monumentos toledanos del Alcázar, la Catedral y los puentes de San Martín y Alcántara. Mandado levantar por el arzobispo cardenal Luis Manuel Fernández Portocarrero y Guzmán (pontificado toledano 1677-1709), es la mejor guía visual de lo que llegó a ser el arzobispado de Toledo. 
Arzobispo, etcétera; por cierto que casi todos estos edificios tenían al frente su propio alcaide y una mínima guarnición nada pertrechada, que no obstante pregonaban la gloria de su señor ${ }^{19}$.

Aparte de esta realidad histórica y material, de lo que no hay duda es de que toda esta grandeza histórico-clerical contaba con buenos panegiristas, una intelectualidad mayoritariamente clériga -valga la redundancia- que estaba a tono con grandes y encendidas descripciones de la urbe por excelencia, de la ciudad toda a decir de Baltasar Gracián. Bebiendo de la larga tradición medieval (desde un san Isidoro o un san Ildefonso, pasando por la llamada "Escuela de Traductores", o Escuela Alfonsina más bien) y aupándose al Humanismo, Toledo contaba con una difusa escuela que vivía en y se nutría del espíritu urbano, por civil pero también por episcopal. Y este paisaje, cada vez más cristianopolitano, empezó a ser cantado con plumas y con pinceles, empezando por el más conspicuo del $\mathrm{Greco}^{20}$. De hecho, Toledo se convirtió en un tópico, o mejor, en una guía o paradigma de lo que tenía que ser una ciudad de la Monarquía Católica, y, sobre todo, de su imagen y propaganda. Podría ser, fácilmente, la deliberada implantación un modelo confesional que más tarde devendría en una ciudad levítica y conventual, en donde decaerían otras visiones republicanas y monárquicas ${ }^{21}$. No faltaban mecenas y gentes de economía holgada en el arzobispado y en el cabildo primados. Por ello, salieron al quite gran cantidad de historiógrafos propios, como Alcocer (el príncipe en castellano), Pisa o su antagonista Román de la Higuera, más el Conde de Mora, Lozano; o ajenos como Medina, Garibay, Ocampo, Morales (el arqueologista), Mariana, y hasta Flórez... En todas sus historias urbanícolas al uso, aparte de su identificación con la monarquía española, las diferentes ciudades rivalizaban por ser las primeras en la instalación en su seno de la Ciudad de Dios, las primigenias cristianas en donde la contaminación musulmana o judía se reducía a la mínima expresión; aunque tanto hispanismo se redujera en la práctica al reino-corona castellanos ${ }^{22}$. De todas formas, no olvidemos que a la historia, más o menos intencionada en sus fines, había que añadir la corografía, la descripción geográfica, que escapaba todavía menos al aspecto clerical porque era más palpable. La mitología fue sustituida por la hagiografía o la episcografía, y los héroes se transformaron en santos. A la postre, un cristianismo acrisolado, lleno de fundadores, testigos, canonizados y líderes archiepiscopales, personal confesionali-

19 La precaria situación defensiva del gran señorío archidiocesano en tiempos de Cisneros en García Oro, J.: La Iglesia de Toledo..., op, cit. infra (nota 33), pp. 33-40.

20 Sobre el particular y estudios sobre el lienzo grequiano, v. de nuestra cosecha "Castile, crown of oligarchic republics. Visions and interpretactions of the urban in Early Modern Spain ( $16^{\text {th }}$ to $17^{\text {th }}$ century)", en Fray, J.-L., Pauly, M., Pinheiro, M., Sheutz, M. (Ed.): Urban spaces and the complexity of cities, Böhlau Verlag, Köln 2018, pp. 233-243; "El Greco "famoso pintor", y los intelectuales cristianopolitanos de Toledo. (A propósito de sus retratos letrados", en Tiempos Modernos, 37, (2018/2), pp. 187-220; "Un reino de repúblicas encantadas. Una reflexión desde Toledo sobre las invenciones ciudadanas españolas (siglos XVI y XVII)", en Bénat-Tachot, L., Blanco, M., Guillaume-Alonso, A., Thieulin-Pardo, H. (Dir.): L'invention de la ville dans le monde hispanique (XI ${ }^{e}$-XVIII ${ }^{e}$ siècles), Paris, Editions Hispaniques, Université Paris-Sorbonne, 2019, pp. 255-281.

21 Seguimos muy de cerca las notas del profesor R. López Vela en "Historiografía y ciudad. El debate sobre el Toledo en el Humanismo y la época confesional", en López Vela, R. (Ed.), Ciudades, gentes e intercambios en la monarquía hispánica en la Edad Moderna, Santander, Ediciones Universidad de Cantabria, 2019, pp. 133-194.

22 Es el caso de la competencia que se entabló entre la mismas sedes metropolitanas o arzobispales de Toledo y Sevilla. V. nuestro artículo "Símbolos de autoridad y poder ciudadanos en el mundo hispánico moderno: la confrontación historiográfica toledano-hispalense", en Revista de Historiografia, 16 (Monográfico La ciudady la construcción de la modernidad. Identidades urbanas y mitologías ciudadanas (siglos XVI-XIX), IX, (1/2012), pp. 164-178. 
zado, antecámara de la cristiano-catolicópolis; no sólo de Toledo sino de una Castilla cada vez más desurbanizada y débil, con la excepción de Madrid.

Otro de los lugares comunes al uso es que un clérigo - ya hemos comentado que había bastantes con la suficiente instrucción- hiciera un grandilocuente elogio del paisaje religioso de la ciudad del que se impregnaban hasta los mejores escritores y literatos seculares ${ }^{23}$. En efecto, una de las primeras descripciones eclesiástico-urbanas la tenemos en el cura-párroco de San Vicente, el licenciado (y familia de conversos) Luis Hurtado de Toledo (1523-1590) ${ }^{24}$, quien escribió un sentido romance paseando su mirada desde el punto más alto de la ciudad, la torre mudéjar de la vecina parroquia de San Román ${ }^{25}$. Desde allí podía apreciar un paisaje y panorama eclesiástico tan peculiar, que ha llegado hasta el día presente:

...miraba la gran ciudad/ que Toledo se decía./ Miraba sus lindas torres/ labradas a maravilla,/ miraba sus chapiteles,/ que con el sol relucían./ Miraba todas sus fuerzas/ y edificios que tenía,/ miraba sus fuertes muros/ y cercas y artillería./ Miraba las lindas casas, / miraba a Santa María,/ miraba su torre y obra,/ que nunca se fenecía..."26.

El profesor González Cuenca ha hablado de los toledanistas primitivos, entre los que ha situado al historiador Pedro de Alcocer (1554), al cronista Sebastián de Horozco (padre de diccionólogo Sebastián de Covarrubias), al mismo Hurtado de Toledo y a Francisco de Pisa, sobre el que después hablaremos ${ }^{27}$. A más, indudablemente

23 Aquello tan conocido de Miguel de Cervantes, que hace exclamar a Periandro aquello de: “iOh peñascosa pesadumbre, gloria de España y luz de sus ciudades, en cuyo seno han estado guardadas por infinitos siglos las reliquias de los valientes godos, para volver a resucitar su muerta gloria y a ser claro espejo y depósito de católicas ceremonias! ;Salve, pues, oh ciudad santa, y da lugar que en ti le tengan éstos que venimos a verte!”. (Los trabajos de Persiles y Sigismunda, capítulo octavo, obra póstuma de 1617). Al parecer es una inspiración del poeta a lo divino José de Valdivieso, protegido también del cardenal Sandoval y Rojas, en un inevitable parangón de Toledo con las montañas de Judea (Tierra Santa).

24 Su parroquia, una de las más céntricas, estaba literalmente pegada a través de una tribuna a las Casas de la Inquisición, en torno a la cual se aposentaron poderosos oligarcas y mercaderes conversos, desde luego los Hurtado, más los Palma, Sampedro, Fuente, Torre, etcétera. Un extenso linaje muy bien estudiado por Martz, L.: A network of converso families in Early Modern Toledo. Assimilating a Minority, Ann Arbor, University of Michigan Press, 2003. Sobre la abundancia de mercaderes (mayor que la sesentena) de esta parroquia, especialmente de la seda, v. Martz, L., Porres Martín-Cleto, J.: Toledo y los toledanos en 1561, Toledo, Instituto Provincial de Investigaciones y Estudios Toledanos, 1974, ff. 292-319.

25 Romance de las notables cosas que tiene la Imperial Ciudad de Toledo (c. 1546, impreso). En breve esperamos que vea la luz de la prensa el excelente y exhaustivo trabajo que ha realizado el benemérito profesor Joaquín González Cuenca, titulado Toledo, la contemplada. Cosas notables que tiene la Imperial Ciudad de Toledo (Romance y Memorial). Como puede apreciarse, Hurtado de Toledo sería el autor del memorial toledano contenido en las Relaciones Topográficas de Felipe II, producido en 1576, del que también intenta expurgar los errores de transcripción y concepto de la primitiva edición de Viñas Mey, C y Paz, R., Relaciones histórico-geográfico-estadísticas de los pueblos de España hechas por iniciativa de Felipe II: Reino de Toledo, Madrid, CSIC, 1963.

26 Versos 3 al 16. Santa María era la Catedral. Inmediatamente después habla de las "muchas rentas" de la fábrica catedralicia, sus dignidades y canónigos, racioneros, capellanes y "toda la clerecía", los cantores, los ornamentos litúrgicos, relicarios, retablos, arcas henchidas de dinero, bóvedas, tallas, vidrieras, órganos, solados de jaspe, claustro, capillas, portadas, el palacio arzobispal, etc. Muy en la línea de la guía latina que escribiera Blas de Ortiz (vid. infra nota 28).

27 De todos ellos, y de alguno más como el cordobés Ambrosio de Morales o el doctor Blas Ortiz, ha realizado una atinada interpretación confesional R. López Vela: "Historiografía y ciudad. El debate sobre el Toledo en el Humanismo y la época confesional"... op. cit. (nota 21). 
el puntal de las eclesiástico-descripciones toledanas fue el vicario general Blas Ortiz, que elaboró toda una guía de la Catedral de Toledo para uso y disfrute del príncipe Felipe de Habsburgo, quien se convertiría en un gran aficionado al Templo Primado, sobre todo de su música. El libro, en latín, era toda una especie de advertencia o llamada de atención para el mundo católico, incluida -o parangonándose con- Roma ${ }^{28}$. Parecía que este magno templo catedralicio fuera la antena central que irradiara la Primacía Toledana, y así aparece en casi todas las vedutas de la ciudad, sobre todo desde el lado meridional. Por supuesto, de tal capital espiritual, primada de Castilla y de las Españas, del centro de peregrinación émulo de la Roma manierista y protobarroca, se elaboraron guías literarias e incluso planos, al modo casi turístico. No hace falta esforzarse mucho para volver a la Descripción de Pisa y al Plano-Vista del Greco, que el profesor Marías Franco calificó de "lienzos panorámicos, libros paralelos" 29 .

Pero si la realidad descrita y narrada era sumamente esplendorosa -en términos relativos-, a su auxilio vino la inventiva que suplió todo lo que hubiera faltado y ajustó toda la historia y la descripción de la ciudad al perfecto guión cristianopolitano, desde la misma concepción genealogista de la antigüedad, tanto pagana como cristiana $^{30}$. Y a la realidad urbanística y a la invención mitificadora se sumaba el ser escenario de una ciudad eminentemente celebrativa, cruzada por multitud de recorridos y desfiles procesionales, según el calendario litúrgico, y hasta autos de fe, jolgorios por la monarquía y por el éxito de sus empresas exteriores, impetración de protección divina contra los desastres naturales, jubileos y canonizaciones, etcétera, en donde los eclesiásticos llevaban la voz cantante y organizaban sus propias exaltaciones ${ }^{31}$.

Lo cierto es que todo este dinámico paisaje y paisanaje real, vivo y movido durante el Antiguo Régimen, aupado por descripciones más o menos literarias e historiografías menor o mayormente científicas, se llegó a convertir en un tópico iconográfico, en una imagen mística, casi en una marca e hito viajeros, que más tarde, después del Romanticismo y hasta el Postromanticismo, más el turismo actual, ha sido explotado a través de la fotografía y las bellas artes pictóricas; para un Toledo contemplado, meditado, a través del paisaje y del mito, que revela poco a poco su misterio profundo de siglos ${ }^{32}$.

28 La Catedral de Toledo 1549 según el doctor Blas Ortiz. Descripcion Graphica y Elegantissima de la S. Iglesia de Toledo, estudios de Gonzálvez, R. y Pereda, F., Toledo, Antonio Pareja Editor, 1999. No habría otra guía mejor hasta que en 1857 Parro publique por entregas la suya, dedicándole el doble de espacio al Templo Primado que al resto de Toledo.

29 Aranda Pérez, F. J.: Toledo circa 1605. La historia-descripción cristianopolitana de Francisco de Pisa, , Toledo-Cuenca, Ediciones de la UCLM-Antonio Pareja Editor S. L., Toledo 2021, prólogo de Fernando Marías Franco.

30 V. Bizzocchi, R.: Généalogies fabuleuses. Inventer et faire croire dans l'Europe moderne, Paris, Éditions Rue d'Ulm/Presses de l’École normales supérieure, 2010. Original italiano del 2009.

31 Rodríguez González, A.: "Itinerarios sagrados en el Toledo de la Edad Moderna", en Vizuete Mendoza, J. C., Martín Sánchez, J. (coords.): Sacra loca toletana. Los espacios sagrados en Toledo, Cuenca, Ediciones de la UCLM, 2008, pp. 369-398. La Catedral era el punto de salida o de llegada preferido o en todo caso constituía una estación casi obligatoria. Ni que decir tiene que todas las procesiones transcurren entre la multitud de iglesias y conventos que hay en el monte toledano.

32 V. el especial "La imagen de Toledo" sacado en la revista Archivo Secreto, 7, (2018) en homenaje al malogrado José Pedro Muñoz Herrera. 


\section{Un complejo y jerárquico organigrama clericalopolitano}

Todavía existen pocos estudios de conjunto sobre la iglesia toledana en la época moderna, salvo el ya clásico como magistral del recientemente desaparecido fray José García Oro ${ }^{33}$. En todo caso, empezaremos por algo obvio: no es sólo que la archidiócesis toledana fuera colosal en sus números sino que también estaba afectada por una macrocefalia evidente, y es que la propia ciudad de Toledo concentraba casi la mitad del clero secular diocesano; y no digamos nada de su exuberante riqueza ${ }^{34}$. Desde luego, no era una situación ideal pues implicaba dos cosas: que el exceso de clero ciudadano entrañaba una gran cantidad de beneficios sin oficio (espiritual) y que el restante ámbito rural quedaba muy desatendido; por no hablar de la relación inversamente proporcional entre excedentes económicos y la dedicación a la cura de almas. Todavía más lacerante era la distancia entre la ciudad y el agro en el reparto del clero regular: Toledo, junto con Alcalá, albergaba al 47\% de los frailes; mientras, la desproporción para las monjas era todavía mayor, con un $71 \%$ del monto diocesano en ambas localidades ${ }^{35}$. Pero, aunque algunas voces individuales se alzaron contra esta situación, no llegó la hora de la reforma en todo el Antiguo Régimen. Pero vayamos desgranando cada uno de los personajes y estamentos clericales de la Toledo moderna.

\section{a. El Arzobispo Primado en sí}

No hay duda de que la cabeza diocesana y aún ciudadana es el señor -en el concepto de poder-arzobispo primado. Esto aparte de que su papel destacado en la misma estructura de la Monarquía, como Canciller Mayor de Castilla (hipotético director de la alta oficina documental y después Notario del Reino nato), ora la accidental como frecuente presidencia de Castilla (del Consejo Supremo de Castilla, segunda alta magistratura regnícola), ora la cabeza visible de la Inquisición (inquisidor general), le lleva a ser el prelado más visible y poderoso de la Iglesia Hispana, el más significado políticamente, sobre todo cuando a partir de los Reyes Católicos suele apoyar a la Corona dejando atrás viejas veleidades políticas partidistas; y el líder indiscutible de la gran máquina clerical toledana, con diferencia. Su estado era incomparable, y sus recursos y riquezas las mayores, como es bien sabido. No hizo falta para todo ello que viniera Trento, con el reforzamiento del predominio de los obispos sobre sus diócesis, pues desde siempre el arzobispo de Toledo no dejó de crecer en influencia, dentro y fuera de su jurisdicción, en todo el reino. Así, podemos decir, sin ambages, que Toledo, a fuer de cristianopolitana, fue una verdadera episcópolis ${ }^{36}$, aun cuando

33 García Oro, J.: La Iglesia de Toledo en tiempo del Cardenal Cisneros (1495-1516), Toledo, Estudio Teológico de San Ildefonso, 1992. (+2019).

34 Exactamente el 45,9\%, para mediados del siglo XVIII. Donézar Díez de Ulzurrun, J. M.: Riqueza y Propiedad en la Castilla del Antiguo Régimen. La provincia de Toledo en el siglo XVIII, Madrid, Instituto de Estudios Agrarios, Pesqueros y Alimentarios, 1984, p. 111 y apéndice III, datos del partido de Toledo frente a los de Alcalá, Ocaña, Talavera y San Juan. Por otra parte, también había una importante concentración clerical, obviamente, en Alcalá de Henares.

35 Idem, p. 115-116. Había 169 conventos en la provincia, 66 en Toledo, 38 en Alcalá, 31 en Ocaña, 20 en Talavera y 14 en San Juan; pero 40 en la ciudad de Toledo, 38 en la villa de Alcalá, 11 en Ocaña, 15 en Talavera y 4 en Alcázar de San Juan. Recordar que sólo se refieren a la parte toledana de la archidiócesis.

36 Recogemos este concepto episcopolitano de Rubial García, A.: "Iconos vivientes y sabrosos huesos. El papel 
su arzobispo residía la mayor parte del tiempo en otras sedes extratoledanas o en la Corte cabe el Rey y su familia; por no decir que el arzobispo de Toledo era el ordinario real, el cura y el director espiritual del rey de Castilla y de España y que su influencia dominaba incluso la capilla real ${ }^{37}$. Así las cosas, en primer lugar, el arzobispo de Toledo, por fuerza y según la capacidad del titular del momento, fue uno de los protagonistas de la política hispánica, especialmente en la época moderna, en connivencia con la monarquía, y otras veces con roces si se alineaba con el Austria o el Borbón o con el Sumo Pontífice romano ${ }^{38}$. Igualmente podemos considerarlo un portavoz oficioso de la iglesia española, ya que ejercía una presidencia honorífica en los actos eclesiásticos más señalados y en lo jurisdiccional era la instancia superior de apelación para los obispos españoles, más allá de su territorio sufragáneo.

Pero, a pesar de todo esto, todavía se echa en falta, primero, estudios profundos de las trayectorias y personalidades de los arzobispos de Toledo, casi siempre personalidades foráneas de la ciudad. Salvo algunos escuetos episcopologios ${ }^{39}$, las biografías arzobispales toledanas están por hacer de manera sistemática, existiendo sólo algunas salvedades como la de Jiménez de Cisneros ${ }^{40}$, Carranza y Miranda ${ }^{41}$, Quiroga ${ }^{42}$, Aragón Fernández de Córdoba $^{43}$, Portocarrero ${ }^{44}$ o ya en el hemistiquio

de los obispos en la construcción del capital simbólico de la episcópolis de la Nueva España (1610-1730)", Martínez López Cano, M. P., Cervantes Bello, F. J. (coords.): Expresiones y estrategias. La Iglesia en el orden social novohispano, México, UNAM et alii, 2017, pp. 217-266.

37 Era el que concedía las licencias necesarias para el ejercicio del Capellán Real que solía recaer en la importante figura del Patriarca de la Indias Occidentales, cargo que recayó en la figura del arzobispo de Madrid desde que se creó este arzobispado, desgajado del de Toledo, hasta 1963), y que hoy en día se subsume en el Vicariato General Castrense, el único cargo obispal que mantiene presentación real.

38 Como dato curioso, a diferencia de otras monarquías, en la española no había ceremonia de coronación ni de unción, que de haber existido hubiera ejecutado el arzobispo toledano, sino sólo de aclamación pública con pendón real y juramento ante las Cortes, en donde el arzobispo toledano solía ser presidente indiscutible. Por su parte, la Corona siempre estuvo interesada en el nombramiento del primado para controlar tan píngüe parcela de poder político y económico, hasta el punto que no son raros los arzobispos-infantes de España.

39 Desde luego, los libros de historia antiguos siempre incluyen tanto listas de obispos como de santos, y aparte de los toledanos mencionados tenemos al conquense Baltasar Porreño (1569-1639) que escribió varias biografías, desde García Gudiel (1280) hasta Sandoval y Rojas (1618), recabadas por el padre Burriel: B.N., Mss 13025 13027. Por lo demás, los únicos episcopologios modernos de los que nos podemos servir son los de Rivera Recio, J. F.: Los Arzobispos de Toledo. Desde sus orígenes a finales del siglo XI, Toledo, Diputación Provincial, 1973; (aparte del estudio citado sobre Bernardo de Toledo, también del mismo autor): Los Arzobispos de Toledo en la Baja Edad Media (s. XII-XV), Toledo, Diputación Provincial, 1969; el no bien logrado libro político Los Primados de Toledo, Toledo, Diputación Provincial, 1993, acabado de reeditar actualizándolo en 2021; y el que completa la serie, Fernández Collado, Á.: Los Arzobispos de Toledo en la Edad Moderna y Contemporánea. Episcopologio toledano, Toledo, Cabildo Primado, 2017.

40 Como las de García Oro (1993) o Pérez (2014), sin contar las innumerables elaboradas en el siglo XIX y hasta la época franquista, donde Cisneros fue un icono español aunque admirado en casi toda Europa, ver nuestro trabajo "Memoria y fortuna de Cisneros: entre la postergación y el mito", en Cisneros 1517-2017. Arquetipo de Virtudes, Espejo de Prelados, Catedral Primada de Toledo, Antonio Pareja Editor, Toledo 2017, pp. 55-67.

41 Por la insistencia en su polémico caso por parte del jesuita J. I. Tellechea Idígoras, y sus innumerables obras al respecto, entre la que destacamos su monumental Fray Bartolomé de Carranza. Documentos históricos, Madrid, RAH, 1962-1994.

42 Pizarro Llorente, H.: Un gran patrón en la Corte de Felipe II: don Gaspar de Quiroga, Madrid, Universidad Pontificia Comillas, 2004.

43 Por el beato Esteneaga y Echevarría, N.: El Cardenal Aragón (1626-1677), París, Imprentas E. Desfossés, 1929, muy a la francesa.

44 Una biografía provisional en Rodríguez González, A.: Los primados de Toledo, 1666-1709, Toledo, Ediciones Parlamentarias de Castilla-La Mancha, 2006, pp. 163-210. 
contemporáneo, Borbón y Vallabriga ${ }^{45}$; es paradójico que existiera para ello más interés en los siglos pasados que en los presentes, resultado de la pérdida de peso específico de estos grandes personajes en nuestra historia ${ }^{46}$. Urge, por tanto, completar individualmente, retrato a retrato como en la Sala Capitular de la Catedral, las biografías relacionales de los arzobispos de Toledo, para entrever, entre otras cosas, la evolución de la iglesia toledana e hispánica.

Aparte de ser jefe político, incluso de alguna facción cortesana en el Reino, en segundo lugar, los arzobispos de Toledo eran poderosos señores de vasallos, como enseguida veremos. Por tanto también es imprescindible el estudio dominical de sus pontificados, ya que los arzobispos de Toledo se encontraban entre los señores eclesiásticos más importantes de la España bihemisferial y de la Cristiandad, lo que implica no sólo conocer con precisión la topografía de su señorío sino su verdadero alcance señorial, su gobierno y su administración, y que el arzobispo-señor se deslinde en este sentido de su patronazgo alto-cortesano (madrileño-hispánico) ${ }^{47}$. Sin duda alguna, el señorío de los arzobispos de Toledo era peculiar, y aunque se llevara por personas interpuestas, no deja de ser un estudio de caso apasionante que mucho tendrá que decir sobre el papel señorial de la Iglesia española ${ }^{48}$.

Otra prerrogativa arzobispal toledana, de gran repercusión, era la convocatoria de concilios y sínodos, en lo que el Primado seguía una larga tradición altomedieval ${ }^{49}$, que en la época protomoderna se actualizaron con los sínodos de Alcalá de 1480, 1481 y 1483 y sobre todo los cisnerianos de Alcalá de 1497 y Talavera de 1498. Después vino el de Tavera (Alcalá, 1536) antes de los trentinos de 1565 y $1582^{50}$, este propulsado por Quiroga, siguiendo después el impulso con Sandoval y Rojas (1601), Moscoso y Sandoval (1658), hasta el último moderno de 1682 de Portocarrero ${ }^{51}$. De

45 Rodríguez López-Brea, C. M.: Don Luis de Borbón, el cardenal de los liberales (1777-1823), Toledo, Junta de Comunidades de Castilla-La Mancha, 2002.

46 Con todo, contamos con magníficos eruditos auroseculares que al margen de Alcocer, Ortiz, Pisa, Porreño, el conde de Mora o Lozano (Los Reyes Nuevos de Toledo, Madrid, Imprenta Real, 1677, aunque tuvo varias ediciones durante el siglo XVIII), dejaron sus apuntes y notas manuscritas, casi todas conservadas en el Archivo y Biblioteca Capitulares de la Catedral de Toledo, como el obispo segorbino Juan Bautista Pérez y sus Apuntamientos para la historia de los Arzobispos de Toledo, o el ya mentado Porreño y su Historia de los Arzobispos de Toledo, estudiada por J. F. Rivera Recio en 1943.

47 Aún así, pocos estudios serios del patronazgo cortesano de los arzobispos de Toledo se han acometido, salvo la honrosa y magnífica excepción de Pizarro Llorente, H.: Un gran patrón en la Corte de Felipe II: don Gaspar de Quiroga, op. cit. (nota 42).

48 Por otras cuestiones, quizá de exotismo, el mejor territorio estudiado del señorío toledano fue Orán, tomado en 1509 por el mismo arzobispo Cisneros, como reza en los frescos de la Capilla Mozárabe. V. Bunes Ibarra, M. A. de, Alonso Acero, B. (Coords.): Orán. Historia de la Corte Chica, Madrid, Polifemo, 2011.

49 En efecto, hasta el eruditísimo García de Loaysa Girón, preceptor de Felipe III, que ocupó la mitra breve tiempo (1598-1599) realizó la monumental obra Collectio Conciliorum Hispaniae, diligentia Garsiae Loaisa elaborata eiusque vigiliis aucta, Madriti, Petrus Madrigal, 1593; un intento similar realizaría el imprescindible cardenal Francisco Antonio de Lorenzana (1772-1800). Con esto hay que considerar el interés por conservar la liturgia hispánica-mozárabe de Cisneros y Lorenzana, hasta el cardenal González Martín (1971-1995).

50 Fernández Collado, A.: Concilios Toledanos Postridentinos. Estudio y edición, Toledo, Diputación Provincial, 1996. También Fernández Terricabras, I.: Felipe II y el clero secular. La aplicación del Concilio de Trento, Madrid, Sociedad Estatal para la Conmemoración de los Centenarios de Felipe II y Carlos V, 2000, capítulos IV y V.

51 En total se han celebrado en la archidiócesis XXV concilios-sínodos, XVIII visigóticos (397-702), y el resto medievales y modernos. Contemporáneos, sólo uno, el de Toledo clausurado en 1992 por el cardenal González Martín; aunque se ha convocado otro próximamente, para 2024, en los inicios del pontificado del arzobispo Cerro Chaves (2020-). Para los concilios modernos existía una sala de concilios ad hoc, sita en los Palacios 
todas estas magnas reuniones toledanas, dedicadas mayoritariamente a la mejora constante de la disciplina y organización clerical, emanaban sabias directrices incluso litúrgicas que influían incluso más allá de las diócesis sufragáneas, que, por otra parte, abarcaban la mitad del territorio castellano. Pero nada de todo esto cargaba solo en las espaldas del arzobispo. Esta casi monarquía clerical tenía su propio gobierno y corte.

\section{b. El Palacio Arzobispal: corte y gobierno archidiocesanos}

En primer lugar, que los arzobispos, casi siempre procedentes de otros lares y destinos, traían a su propia gente de confianza y que intentaban encajarlas cerca de sus personas en la ciudad primada, es evidente. Podemos recolectar multitud de ejemplos. Alonso Fernández Olando, paje del cardenal Sandoval de su etapa pamplonesa (aunque en su familia habían sido criados desde hacía dos generaciones del mismo linaje, en concreto del arzobispo sevillano Cristóbal de Rojas, tío y preceptor del duque de Lerma), casó con Eugenia Melgar, hija bastarda del canónigo toledano doctor Dionisio Melgar, y por ello se le dotó de una honrosa familiatura del Santo Oficio $^{52}$. Por su parte, el cardenal Moscoso se trajo de su fructífera etapa jienense al repostero Juan López de los Cobos, y aparte de a él, se impulsó a su hijo Diego López de los Cobos como escribano del número, de millones y jurado de Toledo ${ }^{53}$. Pero también, como era de esperar, este mismo mecanismo se daba por el lado de sus clérigos. Está el caso de los criados pretendientes a canonicatos de Sandoval y Rojas, de nuevo ${ }^{54}$. O el del jurista Francisco de Herrera Narbona, de familia toledana de fuerte raigambre conversa, hechura y asesor del cardenal Aragón en muchos de sus destinos italianos, que durante el pontificado de este consiguió una oficialidad del Santo Oficio, un hábito de la Orden de Santiago y, por fin, un canonicato en 1672, aunque sabemos que de ordinario acompañaba a su señor sobre todo en la corte madrileña y que incluso murió cuando él en $1677^{55}$.

El arzobispo de Toledo, magnate del reino, poseía todo un Estado, con palacios, servidumbre, vasallos y funcionarios, en cantidades superlativas para ejercer la apariencia y la propaganda de su persona y puesto central en la Monarquía Hispánica. Honor y lujo y otros gastos de representación (como la misma Caridad Pública) podían ser sufragados no sólo de los cuantiosos fondos arzobispales sino de sus

Arzobispales, que todavía se utiliza, como podemos observar por un plano recogido en el manuscrito Toledo. Su prudente gobierno y las corteses ceremonias con que lo ejerce, del escribano Juan Sánchez de Soria, editado y estudiado por García Ruipérez, M., Toledo, Ayuntamiento, 2004, p. 152. De la mayoría conservamos sus constituciones sinodales incluso impresas. Toda esta información puede muy bien contrastarse con la proporcionada por las visitas ad limina: Fernández Collado, Á.: Los informes de Visita ad limina de los arzobispos de Toledo (1603-1917), Toledo, Cabildo Primado-ITSI-Diputación Provincial, 2015.

52 Archivo Histórico Nacional, Inquisición, leg. 1373, exp. 141 (1618).

53 Ibidem, leg. 363, exp. 91 (1684-1690). Aunque le encontraron notas en su linaje (de ahí la tardanza el resolverlo), el expediente salió adelante.

54 Rodríguez de Gracia, H.: "Nepotes y limpieza de sangre...”, op. cit. infra (nota 78).

55 Aranda Pérez, F. J., Sánchez González, R.: “Jurisprudencia y bibliofilia. La familia y la biblioteca de los Narbona", en Aranda Pérez, F. J.: Letrados, juristas y burócratas en la España moderna, Cuenca, Ediciones de la UCLM, 2005, pp. 253-396, p. 257 y ss. Francisco Narbona fue reprobado la primera vez, lo que le costó un retraso de tres años e ingentes sumas de dinero para pagar lo extraordinario del proceso. Al final, para el canonicato, le valieron los actos positivos del Tribunal del Santo Oficio y del Consejo de Órdenes Militares, o sea, la influencia de la Corte y la Administración Real. Pero lo disfrutó poco tiempo... 
grandes peculios personales. Luis Hurtado recoge hasta 173 personas, entre criados y ministros, pertenecientes a la Casa Arzobispal. Entre los primeros había mayordomos, camareros, gentileshombres, cocheros, lacayos, cocineros, reposteros, mozos, pajes...56; una extensa familia a todos los efectos, con un solícito pater familias como hemos visto, en donde abundaban los viejos criados que indefectiblemente terminan bien colocados gracias a las recomendaciones del arzobispo. Entre los segundos, encargados de la administración y la justicia general y particular, tenemos al Consejo - del que enseguida nos ocuparemos-, a los vicarios generales (en Toledo y Alcalá), a los vicarios foráneos y a los visitadores y arciprestes, con sus respectivas oficinas más o menos nutridas ${ }^{57}$.

Pero la archidiócesis era, por decirlo así, también un vivero de obispos que se desparramaron por todas las diócesis hispanas, incluidas las indianas e italianas ${ }^{58}$, amén del recurso a muchos obispos auxiliares y otros obispos con fuertes contactos con la sede primada y sus cabezas que se promocionan hasta en la Curia Romana ${ }^{59}$. Estos obispos no solo se limitaban a la impartición sacramental (confirmaciones y ordenaciones, como veremos al final) sino que los vemos como verdaderos delegados del arzobispo en varias de sus funciones. Pero ahora veamos algunas de estas magistraturas arzobispales.

Si en la estructura polisinodial de la monarquía había consejos, en Toledo se asentó un Consejo de Gobernación del Arzobispado, con una plantilla fija constituida por un presidente (el oidor más antiguo), cuatro oidores-jueces-consejeros y dos fiscales (para lo civil y criminal), más un relator-secretario, un secretario de cámara (enlace con el arzobispo), un secretario-notario, un secretario de títulos, un archivero, un registrador, un sellador, oficiales amanuenses, portero...; por tanto, una institución de carácter eminentemente judicial-letrado, de origen cancilleresco, que suponía para sus componentes un destino de término, y que conocemos gracias al profesor Gutiérrez García-Brazales ${ }^{60}$. En la época moderna este organismo se ubicó en el Claustro Alto de la Catedral, que en el XVII se uniría por un arco volado sobre la calle al propio Palacio Arzobispal, para volver a este ya en el siglo XVIII, probablemente cerca de lo que sería el Archivo Diocesano, a donde derivaba su documentación. Compuesto por asalariados, el consejo o Audiencia Arzobispal era una especie de alter ego del arzobispo (carácter vice-arzobispal) que atendía el gobierno ordinario judicial-administrativo de la archidiócesis (causas temporales-señoriales) pero también era un tribunal superior de apelación tanto de las propias instancias in-

56 Hurtado, op. cit. (nota 25), capítulo 49

57 Los visitadores no dejaron de tomar fuerza hasta constituir una jurisdicción autónoma, mientras que los arciprestes suponían cada vez más una reliquia medieval.

58 Casi un centenar para la época moderna, como recoge Fernández Collado, Á.: Obispos de la Provincia de Toledo (1500-2000), Toledo, Estudio Teológico de San Ildefonso, 2000.

59 Como el caso del humanista y áulico Diego Ramírez de Villaescusa $(+1537)$, hechura de fray Hernando de Talavera y de Cisneros, que tras Astorga, Málaga y Sevilla terminó su trayectoria como obispo de Cuenca. V. Millán Martínez, J. M., Martínez Soria, C. J. (Coords.): Diego Ramírez de Villaescusa: obispo y mecenas, Cuenca, Ediciones de la UCLM, 2009; Sáez Olivares, A.: El obispo Diego Ramírez de Villaescusa y su papel como mecenas de las artes, Madrid, Dykinson, 2021. Por no hablar del moltanbanense cardenal Pedro Pacheco Ladrón de Guevara que terminó sus días como virrey napolitano (sucesor nada menos que de Pedro de Toledo) y como obispo de Albano (+1560); o su sobrino el cardenal Francisco Pacheco y Toledo, arzobispo de Burgos $(+1579)$ y su resobrino Andrés Pacheco de Cárdenas, inquisidor general y patriarca de las Indias $(+1626)$.

60 Gutiérrez García-Brazales, M.: "El Consejo de la Gobernación del Arzobispado de Toledo", Anales Toledanos, XVI, (1983), pp. 63-95; y XXV (1988), pp. 109-140. 
tradiocesanas (civiles-señoriales y eclesiásticas, primera y segunda instancia) como de las diócesis sufragáneas, lo cual resultaba un espacio metropolitano-jurisdiccional colosal. Es evidente que un arzobispo básicamente absentista, no sólo tenía que resignar las cosas de casa a un vicario general o a una serie de obispos auxiliares, sino que necesitaba todo un consejo de gobierno con plenos títulos e igual tratamiento honorífico (señoría ilustrísima y reverendísima). La nómina de asuntos, más o menos menudos, era enorme y muy variada como difícilmente delimitada -como todas las jurisdicciones del Antiguo Régimen-, pero entre las más repetidas del ámbito puramente eclesiástico estaban el funcionamiento de las parroquias, velar por el correcto nombramiento de los clérigos, todo lo relacionado con los beneficios eclesiásticos, cualquier cuestión ateniente a la disciplina eclesiástica (que se ajustara a la prescripción trentina), la erección de iglesias y lugares de culto o su enajenación, así como la constitución de cofradías, apelaciones de los clérigos diocesanos y sufragáneos, congruas de ordenantes y licencias sacerdotales, etcétera; poseía jurisdicción privativa en asuntos de capellanías y beneficios, de enajenar o permutar bienes eclesiásticos, en las causas criminales contra canónigos y dignidades... Como era de esperar, los consejeros eran graduados y expertos canonistas espigados de entre los vicarios, los visitadores o los prebendados catedralicios. Entre los más destacados que rindieron sus servicios en este alto consejo fueron el licenciado Ceballos (que fue oidor desde 1631 y su presidente desde 1639 hasta su muerte en 1644) ${ }^{61}$, o el cultísimo doctor Salazar de Mendoza ${ }^{62}$.

El Consejo Arzobispal fue reformado en varias ocasiones ${ }^{63}$, pero no sobrevivió al Antiguo Régimen. Sí los vicarios del obispo, aunque entonces existieron dos generales (uno para Toledo y otro para la sede complutense), más otros pedáneos o foráneos repartidos por la archidiócesis (Alcaraz, Ciudad Real, Cazorla, Huéscar, Orán, Talavera de la Reina, Alcázar de San Juan y Madrid, la tercera más apetecida), entre los que existió más de alguna interferencia, como con la Inquisición o la orden de San Juan, como era de esperar. Igualmente había visitadores generales, para la misma ciudad y el resto del arzobispado ${ }^{64}$. Con todo, tampoco debemos obviar la importancia de los contadores mayores de rentas, encargados autónomamente de la distribución terciada del diezmo y del arrendamiento del mismo mediante subastas

${ }_{61}$ Aranda Pérez, F. J.: Jerónimo de Ceballos: un hombre grave para la república. Vida y obra de un hidalgo del saber en la España del Siglo de Oro, Córdoba, Servicio de Publicaciones Universidad de Córdoba, 2001.

62 Kagan, R. L.: "Pedro de Salazar de Mendoza as Collector, Scholar and Patron of El Greco", Studies in the History of Art, 13, (1984), pp. 85-92; Gómez Vozmediano, M. F., Sánchez González, R.: "Pedro Salazar de Mendoza (1549-1629): cronista nobiliario y bruñidor de linajes", Tiempos Modernos, 8, 31, (2015), pp. 393-422; Rodríguez Solís, J. J.: “La Monarquía de España desde Castilla. Identidad y reinos en la obra de Pedro Salazar de Mendoza", Espacio, Tiempo y Forma. Historia Moderna, 30, (2017), pp. 335-360.

63 Gutiérrez García-Brazales, op. cit. (nota 60). En el arzobispado de Alberto de Austria aunque promovidas por su sucesor García de Loaysa (Rodríguez de Gracia, H.: "La visita eclesiástica...", op. cit. (nota 64)), en el del Cardenal-Infante Fernando de Austria, en el del cardenal Moscoso y Sandoval y en el del Conde de Teba (ya en 1768).

64 De su inspección quedaban fuera, como veremos, los conventos femeninos y las instituciones pertenecientes al Patronato Real. V. Rodríguez de Gracia, H.: "La visita eclesiástica en el arzobispado de Toledo. Conforme a las Instrucciones de los arzobispos Alberto de Austria y García de Loaysa", Toletana. Cuestiones de Teología e Historia, 8, (2003), pp. 149-197. Paradójicamente, si Trento impuso la visita diocesana, a partir del mismo los obispos toledanos difícilmente pudieron ejercerla personalmente, por lo que tuvieron que designar delegados que referían su trabajo al Consejo de Gobernación, como refleja Gutiérrez García-Brazales, M.: "La Audiencia Arzobispal de Toledo", La administración de justicia en la Historia de España, Guadalajara, Junta de Comunidades de Castilla-La Mancha, 1999, pp. 611-628. 
públicas ${ }^{65}$. También pululaban por dichos departamentos un crecido número de procuradores, casualmente igual al de los escribanos públicos de la ciudad (33). Cada uno de los departamentos vicariales contaba con su propia estructura de audiencia, con su vicario, su promotor fiscal, promotor de obras pías, fiscal de vara, notarios del número, oficiales mayores, receptores, alcaide y pertiguero (la de Toledo, la más importante, tenía también una treintena de miembros). Sus sueldos eran relativamente modestos porque se entendía que vivían principalmente de sus propios beneficios eclesiásticos. Por lo general, eran cargos de confianza, lo que suponía que hubiere ceses y nombramientos con cada nuevo prelado. Ni que decir tiene que la mayoría de estos altos cargos eclesiásticos eran ocupados por eclesiásticos letrados, algunos de enorme valía que derivaron a obispados o a los consejos centrales de la monarquía, aunque también podemos encontrar algunos seglares en los puestos de fiscalía o secretaría en los principios de su carrera, como el caso de los archiconocidos Melchor de Macanaz o Pedro Rodríguez de Campomanes. A toda esta estructura judicial le correspondía penalmente un precario sistema de prisiones arzobispales, con varios centros en la archidiócesis, generalmente en las cabezas de los vicariatos. Finalmente también tenemos que tener en cuenta la gran cantidad de abogados y agentes arzobispales que se movían entre estas instituciones y otras, incluida la Curia Romana, la Congregación del Clero o de las Iglesias de Castilla y León, o altas instancias civiles madrileñas. De su acción tenemos muchos testimonios en los archivos diocesanos y vaticanos.

Un apunte más, hasta ahora poco considerado, sobre el que se debe llamar la atención. También al Arzobispo de Toledo le correspondía la administración, era el comisario general, de la famosa Bula de Cruzada, una de las tres gracias que la Iglesia española derivaba hacia las necesidades, sobre todo militares, de la Corona; aunque fue también un buen ingreso para la propia iglesia hasta los mismos tiempos contemporáneos. La cuestión es que, al igual que el Voto de Santiago ${ }^{66}$, era un asunto religioso-hacendístico que abarcaba al conjunto de la Monarquía Hispánica, y que en el caso de la Bula se extendió a América y a Italia ${ }^{67}$. Por ello, es una fuente óptima, una contabilidad muy completa, para la investigación en múltiples aspectos no sólo de la diócesis toledana sino para nuestra antigua monarquía universal, tanto a nivel local como a nivel general ${ }^{68}$. No obstante, otro verdadero alter ego del obispo venía a ser el cabildo de su sede catedralicia.

65 Las tazmías que iban, grosso modo, para el arzobispo, el cabildo y las parroquias, y que eran la base patrimonial eclesiástica en general. V. el elaborado modelo contable en Villaluenga de Gracia, S., Quesada Sánchez, F. J.: "Rentas, gastos y administración de la Obra y Fábrica de la Catedral de Toledo en la primera mitad del siglo XVI", Pecvnia, 1, (2005), pp. 201-227.

${ }_{66}$ Rey Castelao, O.: El Voto de Santiago en la España Moderna, Santiago de Compostela, Universidad, 1984.

67 Para su estudio todavía es imprescindible el clásico de Goñi Gaztambide, J.: Historia de la Bula de Cruzada en España, Vitoria, Victoriensia-Seminario, 1958.

68 Hasta hace poco, existía un nutrido como amontonado Archivo de la Santa Cruzada en una dependencias del Palacio Arzobispal, constituido en 1529 y depositado allí desde 1930. Ahora es otra de las grandes adquisiciones del unificado Archivo Diocesano de Toledo. Además, se da la circunstancia que las susodichas bulas se imprimían en régimen de monopolio en el cercano y grandilocuente convento dominico de San Pedro Mártir, un verdadero emporio, hoy sede universitaria. V. Serrano Rodríguez, E., Gómez Vozmediano, M. F.: "Imprenta, dinero y fe: la impresión de bulas en el convento dominico de San Pedro Mártir de Toledo (1483-1600)", Tiempos Modernos, 27, (2013/2), pp. 1-65. 


\section{c. Un Cabildo Primado en un Templo Primado}

Es llamativo, aunque comprensible, que la parte del clero toledano mejor descrita siempre es la que sirve y pulula en la Catedral, en la llamada no sin razón Dives Toletana. Y es que es la institución eclesiástica más poblada de la diócesis y, con diferencia, de nuestra ciudad santa; y, a más, ocupa la parte central de todos los paisajes urbanos, gráficos o escritos; por no decir que era una ciudad santa en sí misma dentro de la ciudad santa, una Jerusalén celestial por excelencia. Era un polo de atracción ad gentes y en donde la máxima solemnidad litúrgica y artística tenía lugar; el summum y la vez la summa de la iglesia toledana. De que nos encontramos ante un cabildo dimensionado a una extraordinaria archidiócesis es sintomática la continua ampliación del coro, que necesitó de dos solemnes pisos desde finales del siglo XV a mediados del siglo XVI ${ }^{69}$. En la descripción del templo y de su nómina de servidores, del más alto al más bajo rango, marcaría la pauta el vicario general doctor Blas Ortiz en su elegante obra latina Summi Templi Toletani perque graphica descriptio ${ }^{70}$. Él ya acuña la cifra aproximada de 600 servidores catedralicios $^{71}$, entre clérigos (403) y demás músicos y cantores, lectores, acólitos y operarios, casi todos laicos. En concreto, protocolaria y realmente, en silla alta coral se situaban 14 dignidades, 40 canónigos prebendados y 50 racioneros, mientras que en silla baja lo hacían 20 canónigos extravagantes, 48 capellanes y entre 20 y 37 capellanes maitinantes (nocturnos); más 194 capellanes y sacristanes de capillas particulares, 4 lectores, 12 cantores y 40 clerizones (monaguillos, incluidos los seises); y hasta 150 trabajadores al servicio del templo primado, incluso de su Obra y Fábrica ${ }^{72}$, más o menos cualificados... En el coro, las dignidades se vertían a derecha e izquierda del centro arzobispal, esto es: arcedianos de Toledo y Talavera, capiscol-cantor, tesorero, arcediano de Calatrava, abad de Santa Leocadia y vicario coral; y deán, arcediano de Madrid, maestrescuela, arcedianos de Guadalajara y Alcaraz, abad de San Vicente de la Sierra y capellán mayor. Estas dignidades y los canónigos estaban controlados férreamente por la comisión de los puntos, las asistencias obligadas a los rezos canónicos que tenían que realizar en un mínimo de 90 a 60 días, según los casos. Pedro Alcocer, un lustro más tarde, aumentaría ligeramente la cifra de clérigos a 416, aunque disminuiría la de capellanes particulares a 169, si bien con más precisión, como se muestra a continuación ${ }^{73}$ :

69 Franco Mata, Á.: "El coro de la catedral de Toledo", Abrente, 42-43, (2010-2011), pp. 113-165.

70 Traducida al romance castellano por el bachiller Alonso Cedillo, sobrino del racionero maestro Alonso Cedillo, en La Catedral de Toledo 1549 según el doctor Blas Ortiz..., op. cit. (nota 28).

71 Hasta 616 consigna Luis Hurtado, "Memorial de algunas cosas...”, op. cit. (nota 25), capítulo 49. Exclusivamente él recoge 4 clavijeros, 4 ceroferarios, 4 organistas, 8 ministriles (músicos), etcétera.

72 Como su nombre indica, la Obra y Fábrica es un organismo especializado dentro de la Catedral que se encargaba del mantenimiento y engrandecimiento del edificio, y contaba con su propia administración, archivo, etcétera. Fernández Collado, Á.: La Catedral de Toledo en el siglo XVI. Vida, arte y personas, Toledo, Cabildo Primado, 2015, capítulo $5^{\circ}$.

73 Alcocer, P.: Hystoria, o descripción de la Imperial Cibdad de Toledo..., Toledo, Juan Ferrer, 1554, segunda parte, capítulos ii y iii. Que contrastamos con las más tardías de Lozano Parreño y Navarro, op. cit. (nota 4), pp. 6-10. Amén de las 14 dignidades mitradas, 40 canónigos (incluidos el Papa y el Rey de España), 50 racioneros y 600 beneficios o capellanes corales. Después añade 809 pilas bautismales, 4 iglesias colegiatas, 25 arciprestazgos, 25 iglesias parroquiales en la ciudad (5 mozárabes), 3 "capillas públicas, la una con sacramento", 2 iglesias "que no son parroquias", 17 conventos de religiosos y 23 de religiosas, 17 ermitas, 14 hospitales y "recogimientos", 1 universidad "con los privilegios salmaticenses" (colegio de Santa Catalina), 
- Capilla de San Pedro (23 miembros), parroquial, excepcionalmente con 2 beneficios curados, más 20 capellanes ( 2 de ellos de altares particulares), sacristán mayor, y 2 ministros, fundada por el arzobispo Sancho de Rojas hacia 1417. En su fachada se representan las dignidades catedralicias mitradas.

- Capilla de Reyes Nuevos (36), mausoleo real de la dinastía Trastámara castellana (Enrique II, Juan I, Enrique III), con 26 capellanes, capellán mayor, sacristán, 9 capellanes reales de la reina doña Catalina de Lancaster y servidores pertenecientes.

- Capilla de Reyes Viejos (14), mausoleo real de la dinastía Castilla (Alfonso VII, Sancho III, Sancho IV), 13 capellanes, sacristán mayor y demás ministros necesarios.

- Capilla Mozárabe (14) (del Corpus Christi), oficio hispánico, 13 capellanes (uno mayor), sacristán. Fundada por el arzobispo Jiménez de Cisneros en 1504.

- Capilla de San Blas (14), en los claustros, mausoleo episcopal, 13 capellanes, sacristán. Fundada por el arzobispo Tenorio en 1397.

- Capilla de Santiago (5), mausoleo de los Luna, 4 capellanes, sacristán. Fundada por don Álvaro de Luna en 1435.

- Capilla de San Ildefonso (12), 11 capellanes, sacristán y demás sirvientes necesarios. Fundada por el arzobispo Jiménez de Rada en 1215 y refundada por Gil Carillo de Albornoz (1338-1350). Utilizada para las ordenaciones generales.

- Capilla de Santa Elena (7), 6 capellanes y sacristán. Fundada por el arzobispo Mendoza en 1493.

- "Y en las restantes capillas hay 45 capellanías, instituidas por dichos señores, entre las cuales hay tres en las que diariamente se celebran las misas votivas y las que no se pueden celebrar en los lugares diputados", para un total de 28 capillas, provistas todas por el Cabildo mismo.

- Mención aparte merecerá la Capilla "de la milagrosísima imagen de María Santísima del Sagrario, cuya grandeza, adorno y riqueza casi es imposible de escribir en un solo volumen". A la que habría que añadir la bellísima capilla de reliquias del Ochavo, ambas muy próximas a la Sacristía ${ }^{74}$.

Como acabamos de ver en esta amplia nómina de capellanes privados, Toledo estaba bien nutrida de capillas adscritas a panteones reales, en concreto a las de Reyes Viejos, Reyes Nuevos y Reina doña Catalina (de Lascaster) ${ }^{75}$. Por lo demás, los

1 colegio "seglar" (San Bernardino), 4 colegios "para señoras mujeres" y el Colegio "de los Infantes" de Silíceo.

74 Lozano, op. cit. (nota 46). Cuestión aparte era a quien correspondía la presentación y colación-provisión de las capellanías, si al arzobispo, al cabildo o al rey, o a varios. Entre las capillas no mencionadas, situadas la mayoría en los muros laterales catedralicios están las de la Epifanía, Concepción, San Martín, San Eugenio, Santa Lucía, Santa Ana, San Juan Bautista, San Gil, Santa Leocadia, Cristo de la Columna, Piedad, Capilla Bautismal, Nuestra Señora de la Antigua, de doña Teresa de Haro, la Descensión de la Virgen a San Ildefonso, etcétera. También me he servido de la mejor y amplia guía de la catedral toledana, la coordinada por Gonzálvez Ruiz, R.: La Catedral Primada de Toledo: dieciocho siglos de historia, Toledo, Promecal, 2010, que recoge la tradición de guías-catálogos catedralicios desde Parro, pasando por el conde de Mora-vizconde de Palazuelos hasta llegar a Chueca Goitia. Muy útil el monográfico de Franco Mata, Á.: Las Capillas de la Catedral de Toledo. Historia, liturgia y arte, Toledo, Cabildo Primado, 2018.

75 Colomina Torner, J., Arellano García, M.: Catálogo del Archivo de la Capilla de Reyes en la Catedral de Toledo, Toledo, Cabildo Primado, 2015. 
racioneros contaron con una hermandad propia que gestionaba sus bienes y rentas propios, como después lo hizo el clero parroquial ${ }^{76}$.

Todos estos clérigos que pululaban por la catedral, la ciudad, la diócesis y más allá se movían por partidos o, más bien, facciones, entre las que en su momento destacaban los cabildantes de origen converso ${ }^{77}$, o los que se mostraban conniventes con la Corona, frente al Obispo... En todo caso, la realización de pruebas de linaje limpio, amén de provocar una conflictividad indudable - a veces explosiva, otras soterrada y sostenida- ha generado una abundante documentación sin la cual los estudios prosopográficos del clero hubieran sido mucho más difíciles y fragmentarios. Algunos han interpretado estas impertinentes averiguaciones como un subterfugio del asalto de la mediocridad social contra la hidalguía, contra los privilegiados; cuestión distinta es que, aunque los estatutos se mantuvieron durante todo el Antiguo Régimen, tuvieran una efectividad real más allá del siglo que los vio nacer y de algunos casos en los que se aplicaron, por mucho que la combinación de estatutos y persecución inquisitorial (cuyos miembros estaban sometidos al mismo estatuto) pudiera ser terrible. En todo caso, los testimonios de la utilización de este elemento castizo se hacen sentir por doquier, y muchas veces sólo revela las diferentes oposiciones sociopolíticas en una agrupación cualquiera de poder, no sólo en su seno sino contra el arzobispo y su bagaje nepotesco-cortesano; a veces, las mitras no podían contra las birretas o bonetes negros ${ }^{78}$. La cuestión es que la práctica estatutaria catedralicia fue de las más duras del reino, también porque comprometía a los beneficios de los más pingües de la iglesia española, algo que, como hemos mencionado, afortunadamente dejaría un impresionante rastro documental ${ }^{79}$; o que la actividad en el llamado mercado curial fuera frenética ${ }^{80}$.

Pero toda esta maquinaria catedralicia, tanto en la materialidad del edificio y sus enseres como en el sostenimiento de tan numerosa plantilla de empleados, estaba perfectamente engrasada por una experiencia de siglos, de manera bastante ejemplar que muchas veces sirvió de inspiración a la administración civil ${ }^{81}$. En todo caso, y a

76 Archivo Capitular de Toledo, fondo Hermandad de Racioneros.

77 Sicroff, A. A.: Los estatutos de limpieza de sangre. Controversias entre los siglos XV y XVII, Madrid, Taurus, 1985 (original 1960). La implantación de dichos estatutos fue sorpresiva y por primera vez en la propia Catedral de Toledo, en la Capilla de Reyes Nuevos, en 1530. No era el primero, pero fue el más escandaloso y su influjo, por impulso del cardenal Silíceo (Martínez Guijo o Guijarro, un humilde cristiano viejo) se propagó por todo tipo de instituciones, desde luego eclesiásticas, como cofradías, órdenes religiosas, conventos, colegios (empezando por los de Infantes y Doncellas Nobles) y universidades (Santa Catalina); y hasta al mismo cabildo en 1547-48, con confirmación imperial-real en 1556, que de paso había reforzado en el mismo 1548 el estatuto de la de Reyes Nuevos y en 1553 la de Reyes Viejos, esto es, en todas las capillas reales toledanas. De ahí saltaría incluso al Ayuntamiento Municipal de la ciudad ya con Felipe II en 1566, dividiéndose los regidores entre ciudadanos y caballeros, significativamente.

78 En efecto, como narra Rodríguez de Gracia, H.: "Nepotes y limpieza de sangre en la Catedral de Toledo", Historia y Genealogía, 9, (2019), pp. 145-178, hubo una verdadera enemiga por parte del Cabildo a aceptar de golpe a tres criados del cardenal Sandoval y Rojas. Ni la Rota pudo salvaguardar al prelado en su intención clientelar.

79 En efecto, en el Archivo y Biblioteca Capitulares de Toledo hay un extenso fondo de Limpieza de Sangre, unas 3.400 cajas, más sus correspondientes libros de actas. Una primera aproximación a esta realidad en Rodríguez de Gracia, H.: “'Macula infamiae' en los expedientes de limpieza de la Catedral de Toledo (1577-1623), Historia y Genealogía, 7, (2017), pp. 147-188. V. también el caso de Aranda Pérez, F. J., Sánchez González, R.: "Jurisprudencia y bibliofilia...", op. cit. (nota 55).

80 Díaz Rodríguez, A. J.: "Purity of Blood and the Curial Market in Iberian Cathedrals." eHumanista/Conversos, 4, (2016), pp. 38-63.

81 Sobre este cabildo primado tenemos los completos trabajos de Lop Otín, M. J.: El Cabildo Catedralicio de Toledo en el siglo XV. Aspectos institucionales y sociológicos, Madrid, Fundación Ramón Areces, 2003; Fernández Collado, Á.: La Catedral de Toledo en el siglo XVI. Vida, arte y personas, Toledo, Cabildo Primado, 2015; 
lo que el Cabildo propiamente dicho se refiere, ya hemos dado cuenta que estamos claramente en la facción del alto clero que rivaliza en poder (y cultura) con obispos y ministros reales, y a la altura de la nobleza encumbrada, de la que a veces se surtía para sus efectivos. Tampoco es infrecuente encontrar emblemas de las aristocráticas órdenes militares adornando las vestes capitulares y capellaniles, como en el conocido caso del dramaturgo Pedro Calderón de la Barca, capellán de Reyes Nuevos. Por no hablar de que de las filas del clero capitular salían serios candidatos, también por su formación intelectual, para ocupar altos cargos eclesiásticos y civiles, sin descartar obispados ni presidencias de consejos o tribunales ${ }^{82}$. Este poder, como se ha visto, era celosamente administrado en las pruebas de admisión al Cabildo, en donde operaba como verdadero filtro político la limpieza de sangre por estatuto; estatuto que no se lenizó cuando los tiempos de denuncias de abuso arreciaron en el siglo XVII ${ }^{83}$. Las cuantiosas rentas que percibían y el patrimonio inmobiliario que amasaban, entre los primeros del reino, lo merecían ${ }^{84}$; tampoco la exigencia laboral era excesiva al limitarse a sus puntos en el coro, sus reuniones (cabildos) y la asistencia a algunas ceremonias solemnes, noticiándose que muchos cabildantes andaban con demasiada soltura -y a veces gran escándalo-, por ejemplo, entre los mentideros de la Corte y otras casas de buena y hasta mala nota; para otros las ausencias eran más provechosas, ocupándose de asuntos eclesiásticos o civiles en Roma o ampliando sus conocimientos. Empero, el deber de residencia fue un arduo caballo de batalla que muchas veces los propios arzobispos no podían imponer por propia coherencia. De hecho, las relaciones Obispo-Cabildo se vehiculaban más frecuentemente con los vicarios y gobernadores arzobispales, que en el organigrama diocesano venían a ser unos pares. Aunque las posturas episcopalistas tridentinas se fueron abriendo paso en toda la Cristiandad, la convivencia-confrontación entre obispos y cabildos, y en el caso particular de Toledo, podemos decir que transcurrió en un cuidadoso ten con ten ${ }^{85}$.

Por último, tampoco debemos olvidar que al igual que el Arzobispo Primado, el Cabildo Primado ejercía de señor ${ }^{86}$, como incluso lo hacían algunas comunidades

Sánchez González, R.: Iglesia y sociedad en la Castilla moderna. El Cabildo catedralicio de la Sede Primada (siglo XVII), Cuenca, Ediciones de la Universidad de Castilla-La Mancha, 2000. Para el siglo XVIII escasean los trabajos, salvo Jaime Valor, S.: "Las relaciones entre el Cabildo catedralicio de Toledo y la nobleza a través de las actas capitulares del setecientos”, en Fortea Pérez, J. I., Gelabert, J. E., López Vela, R., Postigo Castellanos, E. (coords.): Monarquías en conflicto. Linajes y noblezas en la articulación de la Monarquía Hispánica, Santander, FEHM, 2018, pp. 1145-1155. Tener en cuenta también el trabajo ceñido al pontificado de Quiroga pero con un buen estudio del estado del cabildo en ese momento en Pizarro Llorente, H.: "Los miembros del Cabildo de la Catedral de Toledo durante el arzobispado de Gaspar de Quiroga (1577-1594)", Hispania Sacra, LXII, 126, (2010), pp. 563-619.

82 Basta la observación, siquiera ligera, de los currícula de los canónigos toledanos, cuyo único sucinto estudio lo tenemos en Fernández Collado, Á.: La Catedral de Toledo en el siglo XVI..., op. cit. (nota 72 y 81), capítulo $4^{\circ}$.

83 Como en la época de Olivares, según hace tiempo mostró Domínguez Ortiz, A.: Los judeoconversos en la España moderna, Madrid, Mapfre, 1993, p. 76.

84 Sánchez González, R.: Iglesia y sociedad..., op. cit. (nota 81), pp. 34-45. No faltaban ni los fastuosos transportes de coches de caballos, que ya entonces eran signos evidentes de distinción: López Álvarez, A.: Poder, lujo y conflicto en la Corte de los Austrias. Coches, carrozas y sillas de manos, 1550-1700, Madrid, Polifemo, 2007.

85 Ibidem, p. 62-69. Cuando el vicario general o gobernador del arzobispado procedía de las filas del Cabildo parecían, paradójicamente, arreciar los conflictos, como en el caso del representante del Cardenal-Infante, el canónigo doctor Álvaro de Villegas (1620). Cuando este fue suplido por el cardenal Antonio Zapata, todo un eclesiástico romano, en 1625 las cosas parecieron ir por caminos más pacíficos.

86 Cfr. Moxó, S. de: Los antiguos señoríos de Toledo. Evolución de las estructuras jurisdiccionales en la comarca toledana desde la Baja Edad Media hasta fines del Antiguo Régimen, Toledo, IPIET, 1973. Sobre la formación 
conventuales ${ }^{87}$. Por ello, llegaron a distinguirse dos mesas en la gestión de las villas y lugares donados tanto al arzobispado como al cabildo catedralicio. La del Cabildo dominaba las comarcas de la Sagra y Torrijos, más próximas a la propia ciudad, aunque en diversos grados, hasta el casi absoluto de Ajofrín (como testimonia claramente la fuente de su plaza central), o la mezcla con la jurisdicción ciudadana de Toledo. Aparte de recaudar las rentas correspondientes tenían la facultad de nombrar oficios de gobierno, administración y justicia de sus propios lugares. No obstante, el señorío cabildante sufrirá la presión secularizadora de los Austrias, como todos los demás señoríos eclesiásticos ${ }^{88}$. Con todo, el Cabildo no era el único cabildo de la ciudad.

\section{d. El entramado parroquial latino-mozárabe}

El régimen parroquial, máxime desde el Concilio Ecuménico de Trento, es fundamental para estudiar la permeabilidad del estamento eclesiástico en el pueblo cristiano. No hay duda de que los párrocos eran los encargados de velar no sólo por la salud espiritual de la grey, sino por estar atentos a las condiciones materiales de la vida de sus vecinos-feligreses. Sobre todo, los párrocos eran agentes dobles del poder civil y del poder eclesiástico, del Reino y de la Iglesia (o viceversa), con enorme predicamento. Y nunca olvidemos que, en cuanto a la geografía política, las parroquias ordenaban la trama urbana, no solo para la atención espiritual sino para la distribución de los famosos tributos eclesiásticos, diezmos y derivados, únicos fijos en el Antiguo Régimen ${ }^{89}$. Además, las parroquias no sólo eran iglesias para servicios religiosos sino verdaderos centros cívicos en donde tenían lugar, por ejemplo, las tenidas de las cofradías y hermandades, incluso la organización de la vigilancia o de las milicias ciudadanas, la impartición de la justicia ordinaria a manos de las parejas de los jurados parroquiales o más tarde los alcaldes de barrio, etcétera. La mayoría de la población, aparte de ser cristianos-católicos, súbditos o vasallos, eran esencialmente vecinos-parroquianos, incluso en las altas concentraciones urbanas frente a las rurales, y por ello eran los párrocos los que extendían los documentos de identidad individuales (verdadero registro civil antes del Registro Civil), al tiempo que vigilaban la recepción de los sacramentos ${ }^{90}$. Y, por ende, la vida (en mayúsculas), como la religiosidad -inherente a la anterior- de cualquier persona, transcurría en su parroquia, desde ingresar en la sociedad (bautismo), tomar estado (matrimonial) o

del señorío capitular ver también Izquierdo Benito, R.: El patrimonio del cabildo de la catedral de Toledo en el siglo XIV, Toledo, Caja de Ahorros, 1980. El señorío del Cabildo interesó a las villas y lugares de Ajofrín, Alameda, Alcabón, Alpuébrega, Arcicollar, Azaña (Numancia), Azucaica, Benquerencia, Borox, Canales, Camillas, Cobeja, Esquivias, Fuentelmadero, Illescas (hasta el siglo XIV), La Figueruela, La Pedrosilla, Maqueda (hasta su venta a Gutierre de Cárdenas), Mazaraveda, Mazarracín, Olías, Torrijos, Valdecubas, Yeles y Zalencas.

87 Como el caso de señorío de abadengo del Convento de San Clemente sobre la villa de Azután, Jiménez de Gregorio, F.: Azután, una villa de señorio monástico femenino. (Del siglo XII al año 1839), Toledo, IPIET, 1990; Vizuete Mendoza, J. C.: Azután en el Antiguo Régimen, Toledo, Caja Castilla-La Mancha, 1993.

88 Especialmente en el reinado de Felipe II. V. Fernández Collado, Á.: La Catedral de Toledo en el siglo XVI..., op. cit. (nota 72 y 81 ), capítulo $20^{\circ}$.

89 Lo mismo hacían en el ámbito rural, aun en los grandes villorrios sureños, como muestra magistralmente Gómez Navarro, S.: Iglesia parroquial y medio rural en el Antiguo Régimen. Nuestra Señora de la Asunción de Palma del Río (Córdoba), Madrid, Polifemo, 2020.

$90 \quad$ Mucho se ha discutido a este respecto sobre la naturaleza vecinal como encuadramiento social de los españoles y demás, especialmente en los reinos indianos. V. Herzog, T.: Vecinos y extranjeros. Hacerse español en la Edad Moderna, Madrid, Alianza, 2006. 
esperar la vida eterna (sepultura), aparte de celebrar multitud de fiestas, particulares o comunales... La Reforma y la Confesionalización Católica tuvieron clara esta actitud pro-parroquial y a través de decretos tridentinos y su posterior emanación sinodal diocesana favorecieron el fortalecimiento del clero parroquial (llamado genéricamente, con injusticia, bajo clero), incluso ante el clero regular-conventual; aunque con cierta parsimonia pues dio tiempo a que los gobiernos ilustrados de la segunda mitad del Setecientos y más allá tuvieran que reiterar todas estas intenciones ${ }^{91}$.

Al margen de dos colegiatas casi residuales, dedicadas a la patrona Santa Leocadia $^{92}$, en la ciudad de Toledo se erigirían en el Antiguo Régimen hasta 27 parroquias, 6 de ellas personales mozárabes (Santas Justa y Rufina y Santa Eulalia, las actuales cabezas, y San Lucas, San Sebastián de las Carreras, San Marcos y San Torcuato, algunas casi despobladas). El resto fueron las parroquias de Santiago el Mayor, San Isidro, San Vicente, San Nicolás de Bari, La Magdalena, San Miguel, Santos Justo y Pastor, San Lorenzo, San Andrés, San Bartolomé, San Cristóbal, San Cipriano, Santo Tomé (Tomás Apóstol), San Martín, El Salvador, San Antolín, San Román, Santa Leocadia, San Juan Bautista, San Ginés y la catedralicia de San Pedro ${ }^{93}$. Hacia 1576 se registran en ellas unos 322 clérigos, que ocupan hasta 105 beneficios parroquiales ( 31 curados, 53 servideros y 21 préstamos), más 213 capellanías. Las que más curados tenían eran San Pedro con dos y San Román con cuatro, pero porque agrupaba curatos de parroquias extintas, mientras el resto solo poseen uno, incluidas las mozárabes ${ }^{94}$. Y hay que tener en cuenta que en algunas ocasiones algún clérigo acumula varios beneficios y capellanías, lo cual no estaba bien visto... En 1605 se acopian 29 beneficios curados, 69 simples (servideros) y préstamos y 55 capellanías, eso sí, para una población de 10.775 vecinos ${ }^{95}$. Como ocurría en la Catedral, algunas parroquias tenían anejas capillas importantes y bien atendidas, como el caso de la de San Andrés, con la Capilla de la Epifanía, con coro físico de 13 capellanes flanqueando la capilla mayor, y la Capilla de doña María Dávalos, con 4 capellanes, todos ellos provistos por el Conde de Mora ${ }^{96}$. Todas las parroquias tenían sus instalaciones propias: templo, campanario, bóvedas de enterramiento, cementerio externo, incluso casa sacerdotal y a veces claustro (como San Andrés o San Miguel), con la excepción de la catedralicia de San Pe-

91 Dubert, I.: "La domesticación, la homogeneización y la asimilación de las conductas del clero gallego del Antiguo Régimen a la idealidad del modelo tridentino, 1600-1850”, en El Antiguo Régimen y la Revolución Liberal. Homenaje a Miguel Artola, Madrid, UAM, 1995, vol. 2, pp. 396-477.

92 Ya lo eran en tiempos de Cisneros, la situada extramuros (hoy Cristo de la Vega) y la que estaba contigua al Alcázar. Tenían sus cargos, como el Abad de Santa Leocadia, la mayor parte irresidentes, aunque percibían religiosamente sus dotaciones. V. García Oro, J.: La Iglesia de Toledo..., op. cit., p. 106.

93 Con criterios ya superados puede consultarse la primera monografía de conjunto de Ramírez de Arellano, R.: Las parroquias de Toledo, Toledo, IPIET, 1997 (reimpresión de 1921). En la actualidad solo subsisten en el casco histórico como parroquias nueve, a saber: Santiago, San Nicolás-La Magdalena, Santos Justo y Pastor, San Andrés-San Cipriano, Santo Tomé-El Salvador, Santa Leocadia-San Román, a las que se añade el antiguo monasterio de San Juan de los Reyes, y las mozárabes Santa Justa y Rufina-San Lucas-San Sebastián y San Marcos-Santa Eulalia-San Torcuato, éstas con poco más de 900 parroquianos adscritos.

94 Luis Hurtado, op. cit., capítulo 50. En números absolutos, San Román contaba hasta con 13 beneficios, aunque en la media alta (entre 5 y 7 beneficios) estaban Santiago, San Vicente, San Nicolás, Santos Justo y Pastor, San Andrés, San Bartolomé, Santo Tomé y Santa Leocadia. Hurtado también es el primero que recoge la existencia del Cabildo de Curas, del que ahora hablaremos, en los que sitúa asociados a 52 clérigos.

95 Pisa, F. de: Descripción de la Imperial Ciudad de Toledo..., Toledo, Pedro Rodríguez, 1605, libro primero, capítulo xviii. Además, se informa que un total de 7 parroquias disponían de casa adjunta para el párroco.

96 Biblioteca Nacional, Manuscritos, 11.25931. Informe del regidor Francisco Gutiérrez de Luján (1632). 
dro $^{97}$, inserta dentro del amplio recinto primacial, en su lado norte; que, por cierto, alcanzaba una de las mayores representaciones clericales: 40 clérigos para 415 vecinos $^{98}$. Por lo demás, apenas se han estudiado en todos sus extremos destacadas figuras de este clero, de los rectores, curas o párrocos sobre todo, salvo las personas del longevo licenciado Andrés Núñez de Madrid, el párroco de Santo Tomé que encargó el impresionante cuadro del entierro del señor de Orgaz al Dominico Greco ${ }^{99}$; el párroco y capellán mozárabe doctor Francisco de Pisa y Palma, o el ya mentado poeta y memorialista licenciado Luis Hurtado de Toledo ${ }^{100}$.

Como vemos, reflexionar sobre el sistema parroquial obliga a hacerlo del régimen beneficial, bastante complejo, que a la altura de los datos de la segunda mitad del siglo XVI comprendía en la ciudad nada menos que ese más que centenar de beneficios, entre curados (o curatos, para los plebanos, rectores, curas propios o curiones parroquiales), servideros (personales y residenciales), simples servideros (que pueden ejercerse por un teniente), simples (sin cura de almas), anejos (anexos, de otras parroquias despobladas o desaparecidas) y los préstamos (prestameras, medios préstamos, quintos de préstamos, todos temporales). Por lo demás, como ya hemos visto, el número de clérigos parroquiales en Toledo ascendía a $322^{101}$. No obstante, también se acusa, con fundamento, a este régimen beneficial de ser una rémora para la consecución de un clero parroquial digno y suficiente ${ }^{102}$. Pero quizá quede más pedagógico explicar que en este clero de las parroquias había, verdaderamente, tres tipos o jerarquías de clérigos: los curas, los beneficiados y los capellanes. Los curas -término todavía vigente a nivel general- eran, de manera fehaciente, dobles beneficiados, con potestad de orden y jurisdicción sobre sus feligreses (administradores de sacramentos que podían conllevar derechos de estola y con obligación de instrucción cristiana en los tiempos litúrgicos fuertes y en las pláticas dominicales); estos curas podían ser propios, con plaza en propiedad, y llegar a ser designados párrocos, o bien servideros, o sea, interinos, delegados. Estos párrocos eran la esencia del sistema y a lo largo del Antiguo Régimen, en Toledo y en el resto de las iglesias diocesanas católicas alcanzarían una gran reputación y acarrearían las simpatías y el interés de los diferentes gobiernos de la monarquía, como directores del encua-

97 Introducida recientemente por Rodríguez González, A., Fernández Collado, A., Casteñeda Tordera, I.: Catálogo del Archivo de la Capilla de San Pedro, Toledo, Instituto Teológico San Ildefonso, 2007.

98 Kagan, R. L.: “Contando vecinos: el censo toledano de 1569”, Studia Historica. Historia Moderna, XII, (1994), pp. $115-135$, p. 127. Aunque la palma se la llevaba San Salvador, con 30 clérigos para 126 vecinos... Con todo, en el Archivo Diocesano de Toledo, sala III, hay un fondo de parroquias de Toledo, Guadalajara, Extremadura, Ciudad Real, Albacete, Andalucía y Madrid, por localidades, que convendría explotar con atención.

99 Rodríguez de Gracia, H.: El rostro de un confeso: Andrés Núñez de Madrid, párroco de Santo Tomé (15621601), Ediciones Puertollano, 2017; también Alguacil Martín, E., Domínguez Montero, D.: "Doménico Theotocópuli, Andrés Núñez de Madrid y el pleito por la pintura de El Entierro del señor de Orgaz: un proceso judicial inédito en el Archivo Diocesano de Toledo", Cuadernos de Archivo Secreto, 1, (2019).

100 Sobre Pisa v. la biografía completa en nuestro libro Toledo circa 1605. La historia-descripción cristianopolitana de Francisco de Pisa, Toledo-Cuenca, Ediciones de la UCLM-Antonio Pareja Editor S. L., Toledo 2021; sobre Luis Hurtado, el trabajo, sobre todo literario de González Cuenca, J., Toledo, la contemplada... op. cit. (nota 25).

101 Sáez, R.: "Le clergé des paroisses de Tolède à la fin du XVI' siècle (posibilites et limites d'une recherche", en Tolède et l'expansion urbaine en Espagne (1450-1650), Madrid, Casa de Velázquez, 1991, pp. 205-224, p. 208 y ss. Las cifras las obtiene del estudio de las Relaciones Topográficas.

102 Barrio Gozalo, M.: "El bajo clero en la España del siglo XVIII. Estado de la cuestión, problemas y direcciones de la investigación actual”, Coloquio Internacional Carlos III y su siglo, Madrid, UCM, 1990, tomo I, pp. 793805 . 
dramiento básico de los súbditos-feligreses cristianos. Así, el párroco nucleaba los requisitos fundamentales que debía poseer toda parroquia: distrito fijo, templo, reserva del Santísimo Sacramento, pila bautismal, administración (diezmo y además emolumentos) y archivo, estancias parroquiales y plantilla de servicio. De hecho, en esta labor, a los curas los auxiliarían los mencionados beneficiados y capellanes, sin responsabilidad pastoral directa, dedicados a las devociones asignadas (coros, procesiones, sacramentales, misas), que también podían tener el oficio como propio o como préstamo, recibiendo en cada caso los emolumentos de su beneficio o capellanía o una limosna convenida; la única diferencia es que los beneficiados se referían al conjunto de la parroquia mientras que los capellanes se especializaban en sus propias capillas o altares contiguos, procedentes de fundaciones pías de institución eclesial o laical, como más tarde veremos. No obstante, en la base de toda parroquia, también podríamos encontrar a los famosos sacristanes, que aunque pertenecientes de pleno a la familia eclesiástica no eran propiamente clérigos, aunque tenían un papel destacado en el mantenimiento de las fábricas, de los bienes litúrgicos (incluidas las campanas) y en las zonas rurales era frecuente que se encargaran de la catequesis y por ende de la enseñanza de los púeres. Por lo demás, también en las parroquias, salvo los párrocos, encontramos un complicado panorama de absentismo, ausencias, tenencias y sustituciones temporales, hasta prestameras a título de estudios, servicios o incluso pertenecientes a otros conventos, hospitales, etcétera ${ }^{103}$.

Para todo este armazón parroquial existía un cabildo segundón que agrupaba a los curas y beneficiados parroquiales, tal como existían en otras muchas partes agrupaciones en distinto grado espontáneas del clero parroquial. El de Toledo agrupaba en torno a la cincuentena larga de clérigos y, al fin y al cabo, constituía otra de las instituciones o fuerzas vivas en la gobernanza de la ciudad; establecimiento institucional entremezclado, incluso por lazos de sangre o clientelares, con el resto de las instituciones ciudadanas ${ }^{104}$. Esta especie de gremio-cofradía de curas o universidad de clérigos de carácter eminentemente defensivo tuvo sus primeras preceptivas constituciones ya en el siglo XV, aunque las más definitivas fueron las emanadas del primer sínodo postridentino, esto es, en 1565, que después serían revisadas e incluso impresas en el siglo XVIII (1728 y 1794). Su estructura era peculiar pues sus reuniones o cabildos eran presididos por dos regidores, y los salientes que les auxiliaban recibían el nombre de diputados. También tenía sus oficios propios como secretario (papeles), mayordomo (ecónomo), contador (cuentas), receptor (recaudador), archivero (archivo), solicitador (pleitos), obrero (supervisor de inmuebles), pertiguero (portero), más maestro de ceremonias, sorchantres (cantantes) y caperos (encargados del vestuario litúrgico). Debían celebrar a sus santos patrones (la Virgen, San Juan

103 Candau Chacón, M. L.: La carrera eclesiástica en el siglo XVIII. Modelos, cauces y formas de promoción en la Sevilla rural, Universidad de Sevilla, 1993. La iglesia sevillana es en muchos sentidos homóloga o seguidora de la toledana.

104 Aranda Pérez, F. J.: "El clero parroquial también se acabilda. El Cabildo de Curas y Beneficiados de Toledo", en Aranda Pérez, F. J. (Coord.): Sociedad y elites eclesiásticas en la España Moderna, Cuenca, Ediciones de la Universidad de Castilla-La Mancha, 2000, pp. 237-287. El archivo de esta institución, que se situaba en la base de la torre de la Parroquia de San Nicolás, su sede histórica (en el presbiterio se mantiene un coro de asientos para dicho cabildo), ha sido trasladado hace una década, por razones de mejor conservación, al Archivo Diocesano de Toledo, en donde esperamos que su consulta pueda mejorar gracias a la catalogación que llevó a cabo María del Sagrario Fernández García, justo antes de su traslado. Por lo demás, en el caso del Cabildo de Curas, podemos hacer un cierto paralelismo con el Cabildo de Jurados de Toledo, como puede establecerse entre Cabildo Capitular y Regimiento... 
Evangelista, San Ildefonso), sus puntos de misas, fiestas y aniversarios obligatorios, y todas las memorias y sufragios que se les hubiera encargado a lo largo del tiempo, descargando en esto las obligaciones individuales. Especial relevancia tenía la asistencia a los entierros con su propia cruz, siempre en refuerzo del papel parroquial en el trascendente tema de la muerte. Por lo demás, este cabildo de curas y beneficiados fue un verdadero actor de control y gestión tanto del acceso por concurso-oposición a las rectorías parroquiales como de la formación y moralidad de los candidatos, y también para la realización de todo tipo de inspecciones administrativas (incluidas las visitas pastorales), residencias (análisis del ejercicio de los oficios), revisión de la práctica de los sacramentos, y demás asuntos concernientes al clero collacional. $\mathrm{Ni}$ que decir tiene que las interferencias e incluso los choques con otras realidades eclesiásticas estaban a la orden del día, especialmente con el gran Cabildo Catedralicio, sobre todo a cuenta del reparto de los diezmos o la salvaguardia de sus beneficios propios. Otra labor necesaria era aminorar o mediar en los conflictos entre las parroquias latinas territoriales y las mozárabes personales, o las posibles peleas por el reparto interparroquial de los diezmos y las primicias a cuenta de multitud de incidencias que podían interponer los parroquianos.

Algo que también puede ayudarnos a realizar un estudio integral de la realidad parroquial, aparte del estudio de su cabildo o el de los registros parroquiales, propiamente dichos, y sobre todo para la realidad rural, son las capellanías y fundaciones pías $^{105}$. Estas fundaciones eran una especie de menudeo de la fe en donde la iglesia (generalmente la parroquia) no sólo se beneficiaba de la generosidad extra de los laicos sino que se constituía como una especie de autofagia para alimentar al propio clero doméstico, también con fines identitarios del linaje y afianzamiento del patrimonio y del nombre familiar ${ }^{106}$. Suelen ser contratos que primero se celebran ante un escribano público del número y que después pasan a registrarse en el arzobispado, lo cual facilita su sistematización, más que espigándolas de entre los protocolos notariales. Por ilustrar esto hagamos alusión a un ejemplo que atañe a un personaje interesante, el presbítero Sancho de Moncada, tío del homónimo economista y también presbítero y catedrático doctor Sancho de Moncada, uno de los fundadores de la moderna ciencia de la economía política. ${ }^{107}$ El 14 de julio de 1599 Sancho de Moncada negociaba con el doctor Juan de Rojas y con Lorenzo Muñoz, cura y beneficiado de la parroquial de San Nicolás de Bari (que a su vez representaban a todo el clero parroquial compuesto por dos beneficiados más) la compra de un juro de heredad de 200 ducados para dotar una capellanía, con su capellán, que a su vez fundía dos en una sola: la una en San Vicente, instituida por el bachiller Garci Pérez, tío de San-

105 Aparte de la documentación que pueda quedar en cada parroquia, existe un fondo centralizado en el Archivo Diocesano de Toledo de Capellanías y Fundaciones Piadosas, que es de lo mejor clasificado aunque con un fichero casi clásico, por fundadores y pueblos. Son más de 500 cajas y casi 2.000 legajos. Con todo, sus datos comienzan en el siglo XVII, aunque las referencias al XVI y XV son constantes, lógicamente. También hay una sección de Concursos y Parroquias, pero no hay catalogación alguna. Sobre dicho archivo véanse las consideraciones de Dionisio Vivas, M. Á.: "El Archivo Diocesano de Toledo. Hacia una descripción de sus fondos", Toletana, 24, (2011), pp. 159-195.

106 Como muy bien formula Martínez Martínez, J. A.: "Construyendo la memoria y la eternidad: las capillas, capellanías, ermitas y obras pías de la familia Muñoz de Otálora (siglos XVI-XVIII), Tiempos Modernos, 42, (2021), pp. 72-92, para el caso de la murciana villa de Caravaca de la Cruz

107 El estudio más completo sigue siendo el de Vilar Berrogain, J., "Conciencia nacional y conciencia económica, datos sobre la vida y la obra de Sancho de Moncada", estudio preliminar a la ed. de S. de Moncada, Restauración política de España, Madrid, Instituto de Estudios Fiscales, 1974. 
cho, y la otra en San Nicolás, fundada por Francisca de la Torre, mujer del primer Sancho de Moncada, padres del presbítero en cuestión y en nombre de su hermano Hernando de Moncada ${ }^{108}$. La capellanía, que recaería en miembros del amplio linaje neoconverso, consistía en la celebración solemne y aparatosa de las fiestas de la (Inmaculada) Concepción de Nuestra Señora (8 de diciembre) y de la Exaltación de la Cruz (14 de septiembre), tanto en la capilla de entierro de los Moncadas como en el altar mayor parroquial ${ }^{109}$.

Por ultimar lo concerniente al ámbito parroquial, no hay que olvidar que hay otro asunto relacionado con las velaciones y los matrimonios que se llevaban a cabo en dicho lugar, y era el estudio y la resolución de las dispensas matrimoniales que tenían que sustanciarse en el seno superior de la diócesis ${ }^{110}$.

Con todo, aunque nos estemos centrando en la catolicópolis toledana, la archidiócesis llegó a contar con 854 parroquias en su culmen quinientista, con sus correspondientes curas párrocos y clero adscrito. Así las cosas, hasta ahora nos hemos ocupado de la parte secular del mundo clerical. La realidad es que si no fuera por la clerigalla catedralicia, este clero se vería desbordado por el regular, por las órdenes religiosas. Otro signo de los tiempos modernos.

\section{e. Una península conventual}

No se llegó, como es obvio, a una situación de estado monástico autónomo como en la actualidad lo es el Monte Athos, en Grecia, pero la cantidad y densidad conventual que alcanzó Toledo en la época moderna, y que aunque muy disminuido conserva todavía, nos hacen pensar en una república conventual en el monte toledano, míticamente compuesto por siete colinas y rodeado de agua por casi todas sus partes a modo de península. Otra diferencia es el fuerte componente femenino. No era el único caso en España (y Europa) de ciudad monástica, pero sí que fue, y sigue siendo, el más arquetípico. Una vez más, si no fuera por el contrapeso del arzobispo y el cabildo primados, hubiera sido una ciudad eminentemente claustral.

No hay duda de que los conventos y monasterios ocuparon un lugar primordial en la sacralización del espacio y de los habitantes toledanos, a modo casi de rosario de protección, y que podría hablarse -si no fuera restrictivo- de ciudad conventual; no obstante, los conventos eran verdaderos complejos religiosos, de instalaciones amplias, que fueron y siguen fagocitando amplias áreas del casco urbano, llegando a ocupar áreas enteras del mismo. Esta tendencia obedece a que las diferentes órdenes religiosas que se iban fundando se fueron instalando desde el mismo momento de la Reconquista (1085), aunque el verdadero acelerón fue, obviamente, entre los siglos

108 Archivo Diocesano de Toledo, Capellanías, expediente de Sancho de Moncada, 1600. Los Torre habían sido uno de las familias que encabezaron la rebelión conversa de 1469 en Toledo. Se trata de una de las primeras capellanías cuya documentación se han conservado en el citado archivo, después de varias infaustas destrucciones.

109 Ibidem. Son curiosos los detalles de la celebración de estas fiestas que se habían de hacer por parte de todo el clero parroquial (con casullas), con el acompañamiento de diácono y subdiácono (con sus dalmáticas), órgano, incienso y un mínimo de seis velas de a seis onzas cada una; más un sermón, nos imaginamos que florido, que debía pronunciar un predicador de la Compañía de Jesús al que se le debía pagar ocho reales "de plata castellanos", y del que debía disfrutar también el pueblo de la parroquia en la misa mayor.

110 Y que también necesitaría de un buen estudio sistemático: Archivo Diocesano de Toledo, sala III, con 1.882 cajas desde 1592 hasta 1810, más 731 para el siglo XIX y 246 para el XX. Es ocioso decir lo que esta documentación bien trabajada podría suponer para la historia del matrimonio. 
XV y XVI, tiempos de reformas observantes, con especial incidencia en la ciudad de Toledo y en las villas de Madrid y Alcalá ${ }^{111}$; impulso que se mantuvo in crescendo en los siglos XVII y XVIII, hasta que se sumió en un proceso de desaparición, incluso física, desde la Desamortización del XIX hasta el día de hoy ${ }^{112}$. Entonces le llegará el turno a la Iglesia Secular...

Esta realidad es palpable en casi todas las descripciones y corografías que se hacen de la peñascosa pesadumbre toledana. En el inspirado romance de Hurtado de Toledo se consignan hasta 30 conventos en 1546, a saber:

"Miraba sus monasterios/ que veinte casas había/ de monjas y de beatas,/ sin frailes, que no ponía:/ Santa Isabel de los Reyes/ que hábito pardo vestían,/ San Juan de la Penitencia/ Santa Clara en compañía,/ el Real Santo Domingo,/ la Madre de Dios había/ San Clemente y otro Antiguo/ Santo Domingo tenía,/ que eran muy libertadas/ en su orden y abadía,/ Santa Fe, comendadoras, / San Pablo, jerónimas, / de Ángeles San Miguel,/ Santa Úrsula, agustinas,/ Santa Ana y San Antonio/ que de Padua se decía,/ Santa Mónica, beatas/ de la Reina de Castilla./ Otras de Misericordia, que de esta obra servían;/ otras, de la Vida Pobre/ y mínimas de María;/ las beatas de San Pedro/ que recogidas vivían.

Diez casas había de frailes/ de todas las abadías./ Ese San Juan de los Reyes,/ do los franciscos vivían./ San Pedro Mártir, lucero/ de la santa teología/, donde los predicadores/se ejercitan noche y día/ en estudios de gran ciencia/ para darnos buena doctrina./ También hay San Agustín/ y la Trinidad había./ Miraba la Merced/ los de Santa Catalina./ Mira también los del Carmen/ llamado "Santa María"/ Cuatro de estos están fuera,/ acercados una milla: las Nieves de dominicos,/ de jerónimos la Sisla,/ de Císter San Bernardo,/ que "Montesión" se decía,/ los mínimos en la Vega,/ que nunca carne comían"113.

Pero parece que había más, que crecieron sin parar hasta 37, como consignaría en 1569, y hasta 40 en 1576, todo en la misma vida del cura-rector de San Vicente ${ }^{114}$. Pero estas crecidas cifras no suponían conventos instituidos como tal sino muchas situaciones pre-conventuales, como las beatas, las recogidas, las doncellas, etcétera; otra cuestión es que con el tiempo se conformaran como tal y efectivamente llegaran a la cifra de la cuarentena en el XVIII. El clero regular no había dejado de consolidar sus cifras e incluso de crecer y si nos atenemos a los guarismos del Catastro de

111 Vizuete Mendoza, J. C.: "Lugares sagrados y órdenes religiosas. Monasterios y conventos de Toledo", en Vizuete Mendoza, J. C., Martín Sánchez, J. (coords.): Sacra loca toletana. Los espacios sagrados en Toledo, Cuenca, Ediciones de la UCLM, 2008, pp. 157-187. El abultamiento de Madrid se produce por la capitalidad de la villa, llegando a la cifra de 71 conventos frente a los 49 que permanecen en la capital arzobispal, que son puntualmente recogidos en cuatro mapas con bastante detalle. Ni que decir tiene que hablamos más de conventos para el encerramiento urbano y la vocación mendicante mientras que los monasterios se encuentran más en entornos aislados rurales; aunque todos son monasterios.

112 Cuando se escriben estas líneas, en 2021, tenemos sólo 14 conventos-monasterios vivos y 4 recientemente vaciados de su comunidad-hibernados-, mientras que sigue reaprovechados en otras funciones 16 y han desaparecido totalmente 21. Datos del proyecto CLAUSTRAT reseñado en la nota 1.

113 Hurtado de Toledo, L.: op. cit. (nota 25), versos 243-294. Contaba además muchas ermitas y veintisiete parroquias, más hermandades, cofradías... Pero vamos, que en 30 años subió el número de conventos en 10, en un $25 \%$.

114 Kagan, op. cit. (nota 98), p. 128. En el Memorial de Hurtado (1576) llegarían las fundaciones a 40, más que en Sevilla... 
Ensenada, que pueden suponer el cenit a mediados del XVIII, tenemos que había 758 frailes en 17 conventos y 493 monjas en 23 (total, 40 conventos) ${ }^{115}$; pero, como veremos al final, la familia clerical no sólo se componía de personas consagradas.

El cometido de los frailes era eminentemente pastoral-complementario, mientras que el de las monjas, por la clausura, contribuía al encuadramiento socio-católico de la mujer, tan honroso como el estado del matrimonio. Entre los frailes (pues la mayoría pertenecían a las órdenes mendicantes) destacaba la predicación ${ }^{116}$, los sufragios por las almas y la caridad. Para lo primero eran requeridos ante la presencia del mismo arzobispo en diferentes actos, en la catedral y en todas las instituciones eclesiásticas e incluso civiles de la ciudad (verbi gratia los sermones de cuaresma en el Ayuntamiento); incluso colaboraron como auxiliares en algunas parroquias, aunque en la realidad el clero parroquial secular y el regular competían en la azarosa aunque productiva plaza de las limosnas, los enterramientos y los sufragios. En todo caso, todos los religiosos dependían en mayor o menor medida del ordinario arzobispal, desde luego jurisdiccionalmente; las monjas estaban totalmente bajo su autoridad, bajo una especie de superintendencia de conventos, que velaba sobre todo por evitar la relajación de sus costumbres y de la práctica de la clausura. Otra dependencia clara de la archidiócesis, como veremos al final, estaba en las ordenaciones (menores y mayores), a donde acudían miembros de todas las órdenes y de todas partes a las ordenaciones generales y particulares ${ }^{117}$. En otro orden de cosas, quedan las adaptaciones que todas las órdenes religiosas, como el resto de las agrupaciones sociales de honor, tuvieron que hacer respecto a la forzada y estatutaria exclusión de la limpieza de sangre ${ }^{118}$. En todo caso, para su estudio también habrá que repasar los hasta ahora poco o nada utilizados fondos del Archivo Diocesano de Toledo ${ }^{119}$.

A manera de ilustración de esta riqueza de la vida monacal toledana ofrecemos unas cifras exactas extraídas de los escritos del doctor Pisa según órdenes religiosas, para comienzos del siglo XVII ${ }^{120}$ :

115 Santaolaya Heredero, L.: Una ciudad del Antiguo Régimen: Toledo en el siglo XVIII. (Personas, propiedad, administración), Madrid, UNED, 1991. Frente a estos el clero secular se componía de 190 presbíteros en la Catedral, 35 canónigos, 44 racioneros, 11 capellanes, 78 presbíteros parroquiales y 184 capellanes varios (642 frente a 1.251). Y siguiendo con las cifras del Catastro y Santaolaya, la Iglesia en su conjunto era dueña del $81 \%$ del patrimonio ciudadano (el 70\% de las casas, la mayoría alquiladas, entre la Catedral, los conventos, las parroquias, las fundaciones benéficas; el $94 \%$ de los censos y el $84 \%$ de los juros; y el mayor propietario de tierras, por supuesto.

116 La predicación era el núcleo de su labor apostólica. V. Negredo del Cerro, F.: Los predicadores de Felipe IV. Corte, intrigas y religión en la España del Siglo de Oro, Madrid, Actas, 2006. También menudearon las críticas hacia los excesos de la oratoria sagrada como la que observamos, sin ir más lejos, en el Fray Gerundio de Campazas, alias Zotes, del jesuita José Francisco de Isla.

117 Véase la tabla de religiosos ordenados presbíteros entre 1663-1698 elaborada por Rodríguez González, A.: Los primados de Toledo, 1666-1709..., p. 99, que asciende a 2.724 (por 3.265 seculares), ni más ni menos, destacando los agustinos, carmelitas, franciscanos, trinitarios, mercedarios (calzados y descalzos), dominicos, jerónimos, jesuitas, menores y mínimos.

118 Aparte de lo comentado en la Catedral, véase, a modo de ejemplo. el caso de la orden que más unitaria permaneció, los dominicos: Pérez García, R. M.: "Dominicos, conversos y limpieza de sangre en España. Siglos XV-XVI", eHumanista/Conversos, 5, (2017), pp. 167-191.

119 Archivo Diocesano de Toledo, Sala III, fondo de Frailes (por órdenes, incluidos los Clérigos Franceses, Cazorla y Desamortización), más el de Monjas, también por conventos y localidades, muy extenso.

120 Toledo circa 1605, op. cit., parte tercera. Donde no aparece número es que no se proporciona en la fuente. 
MONASTERIOS FEMENINOS

\begin{tabular}{|l|l|}
\hline Agustinas & $\mathbf{9 3}$ \\
\hline 1. Purísima Concepción (Gaitanas) & 13 \\
\hline 2. Santa Mónica (a San Torcuato) & - \\
\hline 3. Santa Úrsula & 30 \\
\hline Beatas & $\mathbf{4 3}$ \\
\hline 4. San Pedro ad Vincula (después Benitas) & 13 \\
\hline 5. Santa María la Blanca & 30 \\
\hline 6. Jesús y María (después dominicas) & - \\
\hline Carmelitas Descalzas & $\mathbf{2 0}$ \\
\hline 7. San José & 20 \\
\hline Cistercienses & 230 \\
\hline 8. San Clemente el Real & 150 \\
\hline 9. Santo Domingo el Antiguo & 80 \\
\hline Comendadoras de Santiago & $\mathbf{4 0}$ \\
\hline 10. Santa Fe & 40 \\
\hline Dominicas & $\mathbf{1 6 6}$ \\
\hline 11. Madre de Dios & 66 \\
\hline 12. Santo Domingo el Real & 100 \\
\hline Doncellas seglares & - \\
\hline 13. Doncellas Nobles de Silíceo & - \\
\hline 14. En San Juan Penitencia & - \\
\hline 15. En Santa Ana & - \\
\hline Franciscanas & $\mathbf{3 8 3}$ \\
\hline 16. San Juan de la Penitencia & - \\
\hline 17. San Miguel de los Ángeles & 50 \\
\hline 18. Santa Ana & 60 \\
\hline 19. Santa Clara la Real & 80 \\
\hline 20. Santa Isabel la Real & 70 \\
\hline 21 San Antonio de Padua & 53 \\
\hline 22.Purísima Concepción (concepcionistas) & 70 \\
\hline Jerónimas & $\mathbf{1 3 2}$ \\
\hline 23. La Reina & 30 \\
\hline 24. Vida Pobre & 22 \\
\hline 25. San Pablo & 80 \\
\hline & \\
\hline
\end{tabular}




\section{MONASTERIOS MASCULINOS}

\begin{tabular}{|l|l|}
\hline Agustinos & - \\
\hline 1. San Agustín & - \\
\hline 2. Purísima Concepción (recoletos) & - \\
\hline Carmelitas & $\mathbf{8 4}$ \\
\hline 3. Nuestra Señora del Carmen & 60 \\
\hline 4. Espíritu Santo & 24 \\
\hline Cistercienses & - \\
\hline 5. San Bernardo del Monte Sión & - \\
\hline Clérigos Menores & - \\
\hline 6. Comunidad de San Julián & - \\
\hline Dominicos & $\mathbf{8 0}$ \\
\hline 7. Nuestra Señora de las Nieves & - \\
\hline 8. San Pedro Mártir & 80 \\
\hline Franciscanos & $\mathbf{1 0 0}$ \\
\hline 9. San Juan de los Reyes & 100 \\
\hline Jerónimos & $\mathbf{4 6}$ \\
\hline 10. Santa María de la Sisla & 46 \\
\hline Jesuitas & $\mathbf{5 6}$ \\
\hline 11. Colegio Compañía de Jesús & - \\
\hline 12. Casa Profesa & 56 \\
\hline Mercedarios & $\mathbf{4 0}$ \\
\hline 13. Santa Catalina & 40 \\
\hline Paulinos (Mínimos) & $\mathbf{5 0}$ \\
\hline 14. San Bartolomé de la Vega & 50 \\
\hline Trinitarios & $\mathbf{4 4}$ \\
\hline 15. Santísima Trinidad (calzados) & 44 \\
\hline & \\
\hline
\end{tabular}

No es cuestión de ir glosando, orden a orden y convento a convento la importancia y casi función de cada uno en el organigrama eclesiástico urbano-toledano. Bástenos ahora decir que, como en el caso del arzobispado y la catedral, había gran cantidad de fieles y servidores alrededor de estos centros monásticos y que su consumo (alimenticio, de vestuario, de objetos litúrgicos, de papel, de arte) era impresionante, así como su intervención destacada en el mercado del alquiler de inmuebles (habitacionales e industriales) o el ser beneficiarios de multitud de rentas-cargas hipotecarias, producto de su práctica crediticia censual. 


\section{Intersecciones del clero}

Aparte de una serie de instituciones propias, fuertemente jerarquizadas y organizadas, había otros muchos lugares, administrativos y con presencia física, desde donde la Iglesia seguía acaparando gran parte del tejido y de la sociedad urbanos de Toledo. Veamos.

El tribunal local del Santo Oficio de la Inquisición. Con cargos clericales procedentes de otras instituciones eclesiásticas, también estaba presente en la estructura diocesana toledana la Suprema, el Santo Oficio. En efecto, había un tribunal territorial con su aparato de jueces (inquisidores), fiscales, comisarios (investigadores), notarios-secretarios (del tribunal, del secreto, de secuestros, de actos positivos), calificadores (teólogos), consultores (juristas), depositarios (de pruebas, de confiscaciones), receptores (de multas y también de confiscaciones), alguaciles (persecuciones y arrestos, incluido uno mayor), alcaides (guardián de prisión), abogados de presos, médicos (más cirujanos y barberos), capellanes, porteros, nuncios (mensajeros), etcétera, hasta llegar a la extensa clientela de adláteres y secuaces, los famosos familiares del Santo Oficio, diseminados no sólo en la capital sino en todo el ámbito rural ${ }^{121}$. Estos oficiales, servidores y familiares inquisitoriales estaban, con mayor o menor intensidad, por doquier en el ámbito hispánico, y desde luego el toledano era de los más importantes ${ }^{122}$. En todos estos puestos había, desde luego, multitud de clérigos de todas condiciones, pero en las familiaturas, además, había numerosos laicos abogados, escribanos, notarios, contadores, médicos, boticarios, barberos, mercaderes y hasta labradores y ganaderos. Además, tenían a su cargo la vigilancia de los foráneos, entre los que destacaban los franceses, los portugueses y los italianos; por no hablar, claro está, del celo hacia los conversos y sobre la aculturación de los moriscos. Qué duda cabe que la Inquisición fue otro instrumento de confesionalización, al servicio de la pastoral católica y de las ideas monarcómanas y casi nacionalistas de los Austrias. O que también fue aprovechada como una más de las sinecuras del poder (espiritual-material) dentro de las oligarquías urbanas, tanto clericales seculares y regulares como municipales (como por ejemplo, el caso de los jurados-mercaderes, abundantes en las familiaturas), en un consabido caso de hermanamiento del clero con las clases medias ciudadanas ${ }^{123}$. En cifras concretas, a mediados del siglo XVII había en Toledo unos 76 familiares, al margen de los miembros del tribunal asalariados como tal y sus sirvientes, que llegaban hasta 28 por las mismas fechas, con lo que al Santo Oficio podían pertenecer fácilmente otro centenar

121 Ser familiar reportaba muchos beneficios y privilegios. V. Cerrillo Cruz, G.: “Aproximación al estatuto jurídico de los familiares de la Inquisición española”, Manuscrits, 17, (1999), pp. 141-158; para nuestra zona (tribunales de Toledo y Cuenca) ver la tesis doctoral de Ortega Gómez, L.: Los familiares del Santo Oficio en el mundo rural de los tribunales de Toledo y Cuenca (Ss. XVI-XVIII), Cuenca, Ediciones de la UCLM, 2021.

122 Prácticamente toda la archidiócesis, unos 48.000 kilómetros cuadrados, la mitad de Castilla La Nueva, como incide Dedieu, J.-P.: L'administration de la foi. L'Inquisition de Tolède (XVI ${ }^{e}$-XVIII ${ }^{e}$ ), Madrid, Casa de Velázquez, 1989.

123 Aranda Pérez, F. J.: Poder y poderes en la ciudad de Toledo. Gobierno, sociedad y oligarquías en la Edad Moderna, Cuenca, Ediciones de la UCLM, 1999, pp. 289-307. No en balde, aunque fueran oficios poco o nada remunerados, la adscripción al Santo Oficio ofrecía libertades, exenciones e inmunidades (privilegios) casi eclesiásticos, pero había que estar en condiciones de superar las pruebas de limpieza de sangre. Sobre los curas economistas, sigue siendo imprescindible el estudio de Vilar, J.: "Conciencia nacional y conciencia económica. Datos sobre la vida y la obra del doctor Sancho de Moncada", introducción a su Restauración Política de España, Madrid, Instituto de Estudios Fiscales, 1974. 
de personas, que añadir al dispositivo eclesiástico de la ciudad. Por cierto, que las Casas de la Inquisición estuvieron situadas hasta finales del siglo XVIII casi pegadas a la parroquia de San Vicente Mártir, aquella parroquia del locuaz licenciado Luis Hurtado, hacia donde volaba una tribuna para los inquisidores. Hoy en día su lugar lo ocupa el Palacio Universitario de Lorenzana.

La Pontificia y Real Universidad de Toledo y la formación del clero. En realidad, la universidad toledana, concretada en el modelo colegial de los colegios de Santa Catalina de Alejandría (1520) y San Bernardino (1568), es una emanación de la Sede Arzobispal y Catedralicia, por su fundación y por su mantenimiento académico; si bien el patrocinio del Cabildo Primado no se reducía a los centros propios sino que también sufragaba estudiantes en universidades mayores, como Salamanca, Valladolid (colegios de Irlandeses e Ingleses), Complutense (Alcalá, colegio de San Ildefonso), incluso Bolonia (colegio de San Clemente o Colegio Español). En todo caso, esta relativamente modesta universidad toledana, con un millar de estudiantes de media ${ }^{124}$, hizo las veces de un seminario archidiocesano mayor, el cual, a pesar de los requerimientos trentinos y de ser la diócesis primada, no se llegó a erigir hasta el siglo XIX, pasando del convento de Carmelitas Descalzos al que ocupa en la actualidad en la parroquia de San Andrés desde 1889, con el nombre de Seminario Mayor de San Ildefonso. Tampoco olvidemos el estudio menor del silíceo Colegio de Infantes, fundado en 1552 para la formación de los clerizones de la Catedral, que tenía reserva de becas en el Colegio Mayor de Santa Catalina; como tampoco lo que al tiempo llegaría a ser el Seminario Menor bajo la advocación de Santo Tomás de Villanueva, en 1925, en un palacio mudéjar bajomedieval. No obstante, también se erigieron otros centros superiores en el territorio de la archidiócesis toledana, también universidades históricas, como la de Sigüenza (1489) o la religiosa-conventual dominica de Almagro (1550); por no hablar del Colegio Imperial jesuítico de Madrid (1623), aunque este con un sesgo nobiliario. Hay que tener en cuenta que muchos de los que iniciaban sus estudios en las universidades mayores los terminaban con menos exigencias en estas universidades menores. Ni que decir tiene que la mayor parte de los estudiantes eran candidatos al clero, ensotanados, lo mismo que la mayor porción de los catedráticos, y que lo que más se estudiaba eran Teología y Cánones, dejando las Artes más para los centros religiosos.

Por tanto, la Universidad, de concesión pontificia y real, con sus propias constituciones, venía a ser una comunidad casi religiosa más, por su estructura y su modo de vida. Su patrón o canciller era un canónigo maestrescuela catedralicio, entre los que hubo algunas figuras señeras como el helenista Antonio de Covarrubias, que controlaba la institución mediante visitas y que tenía un vicescolástico, también canónigo, para sustituirlo cuando fuere necesario; el rector solía ser un racionero que tenía sus apartamentos en el mismo edificio; un secretario-archivero para matrículas y claustros; unos ocho capellanes presbíteros para los oficios divinos (la Capilla Universitaria era de gran importancia); los colegiales, con doce plazas becadas sólo durante cinco años de estudio; y los subalternos receptor (economía), sacristán (ser-

124 El estudio inclusivo más reciente es el de Martín López, D.: Orígenes y evolución de la Universidad de Toledo (1485-1625), Toledo, Ediciones Parlamentarias de Castilla-La Mancha, 2006. Sus cimientos descansan debajo de un parking recientemente construido, en la plaza de Santa Catalina, bajo los terraplenes del actual Seminario Metropolitano, con dificultoso acceso. En su momento, sus restos fueron analizados por el arqueólogo Arturo Ruiz Taboada. Mejor fortuna tuvo el Colegio de San Bernardino cuya sede ocupa hoy muy remozada un establecimiento hostelero en medio de la calle de Santo Tomé. 
vicios divinos), refitolero (alimentación), bedel (logística), maestro de ceremonias (escrupulosos actos académicos), alguacil (orden), etcétera. Y por supuesto los catedráticos, unos 13, que ingresaban como los canónigos catedralicios por oposición... Todos integraban el Claustro, que para todo tipo de asuntos de gobierno se reunían en la capilla o en el teatro. Y, como cualquier comunidad religiosa, celebraban sus festividades particulares con sus numerosos capellanes. Tampoco es necesario aquí subrayar la calidad científico-literaria de algunos de sus profesores ${ }^{125}$, pero como ya se indicó al principio de este apartado, no deja de ser una emanación del Cabildo Catedral o, en todo caso, un refugio para elementos sociales conversos que tenían más difícil su promoción incluso intelectual (como el caso de los doctores Pisa, Moncada, Narbona, Palma, etcétera).

Cofradías, hermandades y hospitales. Son-qué duda cabe- extensiones de la acción social de la Iglesia, y, a veces, de una permeabilidad tan exitosa como compleja. Para las Cofradias y Hermandades el balance es proceloso si asistimos a las fuentes diocesanas, y para todo el periodo moderno e incluso el siglo decimonónico ${ }^{126}$. En efecto, entre cofradías, congregaciones, esclavitudes y hermandades tenemos 69 en conventos masculinos (48) y femeninos (21); 15 en hospitales ${ }^{127} ; 282$ en parroquias y 30 en otros lugares (palacio arzobispal, catedral, ermitas, iglesias no parroquiales como Santa María la Blanca); en total 395 referencias ${ }^{128}$. El imprescindible Hurtado cita hasta 147 sólo en Toledo-ciudad, incluyendo toda la serie de las más pías del Santísimo Sacramento (exaltación eucarística, incluido el Corpus Christi) y de las Ánimas del Purgatorio (sufragios y entierros), que estaban presentes en todas y en cada una de las parroquias y que contaban con mayor copia de fieles. En el otro extremo temporal, en 1773 en la ciudad residían 194, de entre 1.887 para toda la provincia toledana, por lo que parece que el movimiento cofradiero se extiende por zonas más rurales ${ }^{129}$. No obstante, la mayor parte de estas cofradías no tienen sede

125 Un buen elenco en Martín López, D.: Orígenes..., op. cit., capítulo 4, al que yo añadiría el maestro Alonso Cedillo, y sobre los que se incidirá en una próxima exposición que celebraremos sobre el V Centenario de la Universidad de Toledo a finales del año presente.

126 Archivo Diocesano de Toledo, Cofradias y Hermandades, 92 legajos clasificados por pueblos, 55 corresponden a la provincia de Toledo. Sobre el particular v. Rodríguez González, A., Sánchez Gamero, J. P.: “Información sobre cofradías toledanas en el Archivo Diocesano de Toledo", Archivo Secreto, 2, (2004), pp. 328-343. Este número de la revista cultural del Ayuntamiento de Toledo tiene un monográfico dedicado a las cofradías toledanas, pp. 289-389.

127 V. Rodríguez de Gracia, H.: Pobreza y beneficencia en la provincia (1500-1800), Toledo, Instituto Provincial de Estudios Toledanos, 1983. Se trata de su tesis doctoral en donde vincula a las cofradías con la labor asistencial-hospitalaria. Similar su obra Asistencia Social en Toledo (siglos XVI-XVIII), Toledo, Caja de Ahorros, 1980. La nómina hospitalera mayor de Toledo, con sus cofradias de socorro, abarca los hospitales de La Misericordia, San Antonio abad, Santos Justo y Pastor, San Lázaro, San Lorenzo, San Juan Bautista (Tavera), San Nicolás, San Pedro, Santa Cruz, Corpus Christi (San Juan de Dios), Del Refugio y Del Rey. Por lo demás, también tenemos el de La Visitación (Nuncio), Santiago de los Caballeros, Caridad, San Ildefonso, Bálsamo, San Miguel, La Concepción y Santa Ana (en subrayado los que aún subsisten o quedan restos).

128 A esta documentación diocesana habría que añadir: las ordenanzas y reglamentos impresos (no menos de 200), los fondos de Cofradías y Hermandades del Archivo de la Diputación de Toledo (procedentes de la Junta Provincial de Beneficencia), lo que pueda espigarse del Archivo Histórico Provincial de Toledo (Protocolos, Hacienda, Catastro de Ensenada), y el fondo de Cofradías del Archivo Municipal de Toledo (con documentación de cofradías nobiliarias, de San Eloy - plateros- y otras residuales).

129 Cruz Palomino, L. de la: "Censo de cofradías de la Ciudad de Toledo del año 1773", Archivo Secreto, 2, (2004), pp. 316-325. Informe del intendente Alberto Suelbes, en la línea ilustrada de corregir abusos y endeudamientos en y de algunas cofradías. Distingue tres tipos de cofradías: sacramentales, de ánimas y socorro, y particulares (de Jesucristo, la Virgen y los santos). 
propia sino que utilizan las instalaciones parroquiales como dijimos en su momento. Cuestión distinta son los hospitales, pues algunos son de gran porte y se adueñan de solares muy significativos dentro y fuera de las murallas de la ciudad, y ocupan a una numerosa plantilla de cuidadores, fijos y ocasionales ${ }^{130}$.

La población eclesiástica toledana en cifras. Al final, la pregunta es obvia: ¿qué población eclesiástica exacta ocupaba la ciudad? Entre seculares y regulares, las cifras que arroja Kagan para 1569, que son una vez más las de Luis Hurtado, son de 600 para la fábrica catedralicia (excesiva para la institución, aunque no todos eran clérigos), otros 321 clérigos seculares (relativamente modesta), más 1.668 religiosos/as (considerable); total 2.589 clérigos; y son de creer por el eminente interés clericalista y la puntillosidad casi estadística del párroco ${ }^{131}$. Además, nos aporta otro dato significativo: la feminización de la población toledana, con un porcentaje del $60 \%$, en el que participa, sin duda, la abundancia de las religiosas que, aparte de ser más numerosas, se concentraban en mayor densidad en sus conventos con una media de 52 monjas por casa. A estas monjas habría que añadir otro colectivo femenino llamativo, las viudas, con casi un $10 \%$ de la población. De todas formas, la proporción de población civil y clerical era de 38 a 1, la más alta de la corona de Castilla, doble que la vallisoletana o la sevillana. Mención especial sigue teniendo las creces de la población clerical regular, que en 1591 incrementa sus efectivos un 16\% más, a 1.942 individuos, con la misma tendencia a la feminización de la vida religiosa (1.339 mujeres por 603 hombres), lo cual, y dada la disminución de la población seglar y secular en adelante, marcaría la tendencia para el siglo XVII ${ }^{132}$. Evidentemente, a la altura de mediados del Seiscientos hasta el del Ochocientos, por fuerza el porcentaje de una población eclesiástica que seguía como si nada hubiera ocurrido demográfica y económicamente, no haría más que aumentar conforme se ahondara el agujero de la decadencia toledana ${ }^{133}$; pero no sería tanto así en la diócesis en general. Todas estas cifras concuerdan, con matices, con la marcha de la demografía eclesiástica en general, que ve como aumenta de manera sustancial las órdenes religiosas -al doble- sobre los curas en el siglo XVII, para tender a equilibrarse a finales del Antiguo Régimen ${ }^{134}$. De la misma forma, son elocuentes las cifras arrojadas desde

130 Pocos hospitales toledanos tienen un estudio a la altura de su importancia, que también subraye su labor asistencial y curativa. V. Rodríguez de Gracia, H.: El Hospital del Rey de Toledo. Contribución a la historia de un hospital toledano, Toledo, INSS, 1985; Zamorano Rodríguez, M. L.: Historia del Hospital de San Juan Bautista de Toledo en el siglo XVI, Madrid, Tesis de la UCM, 1992; Marías Franco, F.: El hospital de Tavera de Toledo, Sevilla, Fundación Casa Ducal de Medinaceli, 2007. Los trabajadores ocasionales son los miembros de las cofradías asistenciales, no asalariados.

131 Para un total de 53.770 habitantes, casi un 5\% de la población, redondeando. Recoge, además, 23 conventos femeninos y 14 masculinos. Kagan, op. cit. (nota 98), p. 119 y ss.

132 Censo de Castilla de 1591, Madrid, INE, 1985-1986, recogido a su vez de González, T.: Censo de población de las provincias y partidos de la corona de Castilla en el siglo XVI, Madrid, Imprenta Real, 1829. Este censo es el que estudia Ruiz Martín, F.: "Demografía eclesiástica", voz del García Villoslada, R. (Dir.): Diccionario de Historia Eclesiástica, tomo II, Madrid, CSIC, 1972. Martínez Gil, F.: Toledo y la crisis de Castilla, 1677-1686, Toledo, Ayuntamiento, 1987, recoge 24 conventos femeninos por 17 masculinos aunque testimoniando que muchos pasan apuros debido a la crisis económico-monetaria general.

133 Montemayor, Julian: Tolède, entre fortune et déclin (1530-1640), Limoges, PULIM, 1996; Rodríguez de Gracia, H.: El crepúsculo patrimonial de Toledo, Toledo, Ayuntamiento, 1999.

134 Barrio Gozalo, M.: El Clero en la España Moderna, Córdoba, CSIC-CajaSur, 2010, cuadro 2. Mientras que en 1591 la proporción es 40.599 a 50.486 (y un 1,1\% de la población total), en 1700 es de 66.000 a $95.000(2,1 \%)$, en $1797,70.840$ a $72.621(1,2 \%)$ y en 1835 de 41.219 a 46.255 (0,6\%). El número máximo de religiosos se dio en 1752 , con 64.147, con un índice de 252 respecto a 1591 y bajando a 121 en 1835 (cuadro 9), mientras que 
el Catastro de Ensenada y otros censos dieciochescos por el profesor Donézar en su estudio de la riqueza toledana ${ }^{135}$.

Las ordenaciones. Pocos testigos hay en el que podamos contemplar una fotografía global de la iglesia architoledana, y esos son las procelosas y multitudinarias ordenaciones $^{136}$. Éstas nos dan el indicio y la medida de la dimensión tanto cuantificada como cualificada del estamento eclesiástico en la ciudad y en la diócesis, un complejo sistema que a priori ocuparía toda una sección del Archivo Diocesano, pero de las cuales se han perdido o extraviado casi todo lo concerniente al siglo XVI y hasta para la mayor parte del siglo XVII; aunque no sabemos si, como en tantas otras cosas, no se ensayó un verdadero control documental hasta que los sínodos tridentinos quisieron poner orden en este maremagnum. Porque lo es, sin duda, la gran cantidad de ordenaciones de diferentes grados, que sobrepasaron las mil anuales, en ceremonias realmente masivas, que a veces excedieron esta cifra en lo que en su momento denominamos una producción en serie, casi fabril, de clérigos de todos grados, probablemente la más importante de las Españas; aunque hay que tener en cuenta que a veces varios grados sucesivos recaían en los mismos tonsurados ${ }^{137}$. Como muestra hemos escogido el primer libro-matrícula de ordenaciones completo conservado que corresponde a la parte inicial del pontificado de Baltasar Moscoso y Sandoval (1646-1665) ${ }^{138}$. Aunque se trató de un cardenal-arzobispo eminentemente pastoral, después del absentista Cardenal-Infante don Fernando de Austria, desde luego las ordenaciones ocupaban muy poco de su actividad episcopal. De hecho, eran sus obispos auxiliares y/o sufragáneos quienes llevaban la carga de otorgar tanto las órdenes menores (corona -tonsura-, ostiario, lector, exorcista y acólito), como las mayores (Subdiaconado o Clérigo de Epístola, Diaconado o Clérigo de Evangelio y Presbiterado o Clérigo de Misa), y en diócesis tan vasta; era una comisión tan agotadora, que la ejercían por poco tiempo y turnándose, y da una cierta sensación de que se expendía este sacramento casi a destajo ${ }^{139}$. En

el de monjas, en la misma fecha (Catastro de Ensenada) fue de 28.938, pasando en 1591 a tener el índice 1000 y en 1835 el 60 (cuadro 10).

135 Donézar Díez de Ulzurrun, op. cit. (nota 34), pp. 109-120. Arroja para la provincia un total de 8.508 personas pertenecientes al estado eclesiástico (en un total de 313.221 habitantes) que comprendían clero secular, regular, colegiales y colegialas, recogidas y sirvientes legos. Total, el 2,7\% de la población. Si sólo nos atenemos al clero como tal, el 2,1\% (2.238 seculares y 4.549 regulares). El clero secular se componía de curas, beneficiados, tenientes de cura, ordenados a título de patrimonio y de menores. Para el Censo de Floridablanca, las cifras disminuyeron a 2.120 y 3.293 respectivamente. La Catedral seguía contando con unas 623 personas. Y entre el clero regular seguían ganando los hombres sobre las mujeres (3.202 y 1.347).

136 Archivo Diocesano de Toledo, sala V entreplanta, Órdenes, (1561-1810: 2.324 cajas; 312 para el siglo XIX y 70 para el XX).

137 En nuestro libro sobre Jerónimo de Ceballos, op. cit. (nota 61), pp. 48-49, ya realizamos una cata en el fondo suelto de Órdenes y entre 1606 y 1618 fue en crescendo desde las 1.000 a las casi 2.000 ordenaciones. Era el pontificado de Sandoval y Rojas.

138 Archivo Diocesano de Toledo, Libro IV/136. Ordenados en tiempos de don Baltasar de Moscoso y Sandoval (1646-1654). El libro fue confeccionado por el secretario Francisco de Morales. El doctor don Baltasar de Moscoso y Sandoval, sobrino del duque de Lerma, había sido canónigo, arcediano de Guadalajara, capellán mayor y deán en Toledo, obispo de Jaén y arzobispo de Toledo, amén de Canciller Mayor de Castilla por esto mismo, más presidente del Consejo de Castilla y consejero del de Estado, amén de cardenal del título de la basílica romana de la Santa Cruz, ni más ni menos.

139 Ibidem, se trata de los obispos de Listria (Istria), Timoteo Pérez de Vargas, obispo sufragáneo-visitador y del Consejo de S. M.; el obispo de Troya, el agustino fray Francisco de Villagutierre Chumacero; y el obispo de Jamnia, fray Pedro de Orozco. El propio cardenal sólo participa en ordenaciones individuales allá donde le pilla (Toledo, Guadalajara, Talavera, Madrid) generalmente de corona (seguramente para criados suyos), o personajes de nota, como en el 17/09/1651 en su oratorio de su casa de Madrid a don Francisco de Moscoso, su sobrino, 
efecto, se recogen dos tipos o tandas de ordenaciones, las particulares y las generales. Las primeras abarcan un número indeterminado, no demasiado nutridas (en torno a la veintena o menos), en las que se especifica con frecuencia la dispensa de trámites o de ciertos impedimentos, y a veces, los diferentes grados clericales se suceden en una misma persona con muy pocos días de margen ${ }^{140}$; en estos casos el lugar señalado para tal ocasión tiene lugar en el oratorio doméstico del obispo (en las casas de Toledo o de Madrid), en la Capilla Arzobispal (previo permiso del Ordinario), y en los templos parroquiales e iglesias monástico-conventuales de toda la diócesis (incluida Orán ${ }^{141}$ ), y siempre ante testigos ${ }^{142}$. Las órdenes generales se realizan pautadamente dos veces al año (marzo y septiembre, viernes tarde, menores y sábado mañana, mayores) y en la Capilla de San Ildefonso de la Catedral, que es la central de la girola y que está en eje con la capilla mayor y su reserva eucarística y el coro; así, por ejemplo, el 20-21 de septiembre de 1646 se ordenaron 69 de corona, 11 de dos grados, 43 de cuatro grados, 2 de dos últimos grados, 12 de epístola, 20 de evangelio y 15 de misa (total 172, aunque sólo 47 de mayores); pero podían juntarse más, como en las generales de marzo de 1648 donde se llegó a los 223 ordenados... En estas ordenaciones generales participaba toda la archidiócesis y aún más allá, por lo que el espectáculo litúrgico resultaría apabullante ${ }^{143}$. Terminada la ceremonia se les proporcionaba los preceptivos títulos por escrito, que después eran registrados en los libros correspondientes.

Clérigos también en el Cielo. Para no faltar a la geografía diocesana, tenemos que hacer alusión al mundo de los santos, a la Iglesia Celestial que acompañaba a

arcediano de Madrid y a don Benito de Azores, capellán de Reyes Nuevos.

140 Ibidem. En el primer caso se le dispensan los intersticios o posee un extra tempora del Nuncio; mientras que en la segunda se aducen cuestiones como la de tener padres desconocidos o ser corto de vista, etcétera. Precisamente los datos que aparecen de los ordenantes son siempre sus padres y su lugar de naturaleza. Llama la atención, sobre todo en el ámbito rural, como se ordenan a posteriori de subdiácono, diácono o presbítero a los curas propios ya designados como tal; esto es, que con los curas pasaba como con algunos cardenales...

141 Ibidem. El obispo de Istria se trasladó allí del 7 al 21 de Julio de 1647 para ordenar en su templo parroquial. Puede que aprovechara la ocasión para realizar visita.

142 Lo cual era un honor. Ibidem. El 20/04/1647 aparece por allí en calidad de tal el doctor don Alonso de la Palma, obispo electo de Ceuta, para que pudiera hacer expresa su nueva condición y para que aprendiera lo que era uno de los principales atributos obispales.

143 Ibidem. Por hacernos una idea, en las órdenes generales del 15 y 16 de marzo de 1652 con el obispo de Troya como principal oficiante, se presentaron candidatos de órdenes religiosas regulares (carmelitas calzados, 7; jerónimos, 3; dominicos, 15; franciscanos descalzos, 16; jesuita); más seculares de Almagro, Villarejo de Salvanés, Villarrubia de los Ojos, Ventas con Peña Aguilera, Huecas, Toledo, Getafe, Almodóvar, Riópar, Cadalso de los Vidrios, Puebla de Alcocer, Almorox, Miguelturra, Mazarambroz, Orgaz, San Martín de la Vega, Robledo del Mazo, Leganés, Valdepeñas, Siruela, Colmenar de Oreja, Buitrago, Santa Cruz de Mudela, Escalona, Cazorla, Guadalajara, Cuerva, Brihuega, Valdaracete, Carranque, El Moral, Santorcaz, Auñón, Talavera, Ciudad Real, Extremera, Puertollano, Almedina, Yebra, Villamanrique, Illescas, Daimiel, Albacete, Agudo, Nombela, El Bonillo, Almadén, Villanueva de los Infantes, La Estrella, Santa Olalla, Majadahonda, Gamonal, Yébenes, Guadarrama, Morata de Tajuña, Albaladejo, Valdetorres, Bolaños, Herrera, Casas de Don Pedro, Alcaraz, Mora, Méntrida, Valdepeñas de Uceda, Malagón, Ocaña, Albalate, Corral de Calatrava, Villafranca de Gaitán, Villaviejas, Villafranca de la Puente, Quesada, Fuenlabrada, Pastrana, La Solana, Torrijos, Esquivias, Sonseca, Puente del Arzobispo, Torija, Mascaraque, Yunda, Humanes, Garlitos, Sabacines, El Prado, Pinto, Móstoles, Casarrubios del Monte, Castellar de Santiago, Mondéjar, Gálvez, Granátula, Almonacid, Valdemoro, Navalcarnero, Chozas y Canales, Piedrabuena, Ajofrín, Fuenlabrada de los Montes, Chinchón, Navahermosa, Manzanares, Parla, Almedina, Talarrubia, Esquivias, Menasalbas, Puebla de don Rodrigo, Saceruela, Villarta, Daganzo, Fuencaliente, Arganda... Incluso dos candidatos de Granada y Mondoñedo. A este respecto, al final del libro se ofrece también un registro de reverendas, que eran como certificados de suficiencia de diferentes grados para ser ordenados en otras diócesis. 
la terrena militante ${ }^{144}$. Aparte de los procesos de canonización, exitosos o no, sustanciados en Roma, la iglesia toledana, como todas las demás, quiso contar con una buena nómina de santos protectores de la ciudad y de la diócesis, para más abundamiento de los patronos antiguos. Aparte del fortalecimiento del culto mariano con la exaltación de la Virgen del Sagrario custodiada en la Catedral y, muy relacionado, la exaltación de san Ildefonso ${ }^{145}$, casi todas las historias y descripciones toledanas proponían una lista de santos o postulantes a su canonización o de santos foráneos que habían intercedido por la ciudad ${ }^{146}$. Por no hablar de hagiografías oficiales, como la del jesuita Quintanadueñas, que no dejaban de ser extensiones de episcopologios, básicamente ${ }^{147}$.

Acogerse a sagrado. Otra intersección, o interferencia, eclesiástica es el ofrecimiento de "acogerse a sagrado" en sus amplios recintos protegidos para salvaguardarse de la justicia civil-ordinaria. Aparte de que la Iglesia tuviera sus propios tribunales e incluso cárceles para los clérigos díscolos, también la intercesión de la Iglesia en sus templos podía dilatar los procesos delincuenciales, en el marco de su ideal irénico ${ }^{148}$. Aunque también podía darse la dirección contraria, que la justicia civil-real podía entrometerse, forzar algunos asuntos judiciales eclesiásticos que lesionaran su esfera preeminente, según el grado de regalismo imperante ${ }^{149}$. Otra prueba más de la mixtificación de la sociedad cristiana y la sociedad laica.

Familias clericales. Otro punto muy interesante es aquilatar con mayor precisión la composición de las familias clericales -más allá de los bandos y los partidos bajomedievales-, en dos aspectos: como se organizaban internamente los clérigos y religiosos entre sí, y como eran sus relaciones con los seglares en esa amplia línea intermedia de los familiares o servidores eclesiásticos. Bastará exponerlo aquí con un par de apuntes. Todavía queda mucho por estudiar pero, por ejemplo, se sabe que en los conventos femeninos, especialmente en los más dotados, había monjas de servicio, literalmente. Eran, por ejemplo las monjas of freilas de velo blanco del con-

144 En el Archivo Diocesano de Toledo, sala IV, se guardan los expedientes de varios candidatos que llegaron a no a algún grado de la canonización, desde doña Sancha Alfonso, infanta de León, y el cardenal Cisneros a los mártires de la Guerra Civil, muchos de ellos religiosas.

145 Pisa (op. cit. (nota 29), parte segunda) indicaba que la primera preeminencia de la Catedral es haber albergado el milagro de la Descensión de la Virgen a san Ildefonso para entregarle la casulla, haciéndolo su capellán y canonizándolo directamente.

146 Volviendo a Pisa, en su primera y segunda parte, aporta la siguiente lista de 34 santos, casi todos clérigos: los arzobispos Eugenio I, Montano, Eladio, Eugenio III, Ildefonso, Julián, Wistremiro, Eulogio de Córdoba, Juan; con títulos de santos Eufemio, Félix, Urbano, Honorato, Fulgencio; dignidades de la Catedral: Evancio, Pedro de Osma, Julián de Cuenca, Giraldo, Gumersindo, Nicolás; santas: Leocadia, Obdulia, Mariana y Casilda; y "santos varones en santidad": don Pelayo, Cisneros, fray Martín Ruiz, Gonzalo Ruiz de Toledo (señor de Orgaz), Niño de la Guardia, María García, María de Ajofrín, María de Toledo, Beatriz de Silva y don Raimundo, abad de Fitero (enterrado en Monte Sión).

147 Quintanadueñas, A. de: Santos de la Imperial Ciudad de Toledo y su arçobispado, excelencias que goça su Santa Iglesia, fiestas que celebra su ilustre clero, Madrid, Pablo del Val, 1651. Es un encargo arzobispal y está dedicada al Cabildo Primado. Aunque mucho antes también hay que tener en cuenta las consideraciones de Alonso de Villegas en su Flos Sanctorum, publicado en Toledo entre 1577 y 1594.

148 López Gómez, O.: “Acogerse a sagrado: violencia, poder y recintos eclesiásticos a fines del medievo", en Vizuete Mendoza, J. C., Martín Sánchez, J. (coords.): Sacra loca toletana. Los espacios sagrados en Toledo, Cuenca, Ediciones de la UCLM, 2008, pp. 189-222.

149 Paradójicamente el primer defensor de los recursos de fuerza fue el licenciado Jerónimo de Ceballos, que como sabemos llegó a gobernador del Arzobispado. V. nuestro libro Jerónimo de Ceballos: un hombre grave para la república, op. cit. (nota 61 ). 
vento cisterciense de San Clemente el Imperial, en donde la situación de noviciado podía prolongarse más de lo debido para mantener a ciertas hermanas en situación de disponibilidad para las monjas de velo negro. Estas, más que en celdas, y merced a su alta procedencia social y a su propia aportación económica, residían en pequeños apartamentos dotados de comodidades ("alhajados"), con sus criadas y todo, con los que incluso llegaban a traficar. Es decir, que algunas mujeres ingresaban en la vida religiosa no (sólo) por vocación sino para ser criadas o damas de compañía de monjas linajudas, a las que se les pagaba la dote ordinaria; algunas no llegarían siquiera a profesar. Hablamos de una especie de freilas privadas, pues no asistían a lo necesario comunitario ${ }^{150}$. Es una cuestión quizá más peculiar que los legos y donados de los conventos y monasterios, dada su enorme riqueza en tierras de labor y en instalaciones en general. De cualquier forma, recordemos que en el Antiguo Régimen, los criados en sus múltiples facetas formaban parte, incluso jurídicamente, de cualquier familia, pues se trataba de un concepto más habitacional que consanguíneo. Otro tanto ocurría con aquellos presbíteros que acogían a otros clérigos y le proporcionaban toda la formación necesaria para llevar a cabo su carrera a cambio de ciertos cometidos en la administración doméstica, como en seguida veremos ${ }^{151}$.

Otro caso muy llamativo son las pequeñas cortes de algunos eclesiásticos. Ya mencionamos la abigarrada Corte Arzobispal. Pero la cuestión es que cualquier clérigo secular notado tenía mucha gente a su alrededor, en su casa, en un combinado de protectorado-formación clerical y mero servicio doméstico. Donde es más fácil observarlo es en los libros del Catastro de Ensenada correspondientes al Estado Eclesiástico ${ }^{152}$. Así, verbi gratia, en 1753 el canónigo y deán -y al poco arzobispo- de Toledo, Luis Antonio Fernández de Córdoba Portocarrero Guzmán Aguilar, conde de Teba (en puridad, un Medinaceli), tenía en sus casas un servicio de 40 personas, id est: 1) una familia de mujeres propia (cuatro, una soltera, otra casada, una viuda y una religiosa) más 8 criadas auxiliares (total, 12);2) otra familia clerical: un presbítero capellán mayor, otro mayordomo-administrador, otro secretario, otro mayordomo de cámara, dos más capellanes, un clérigo de menores de paje y otro de prima de lo mismo ( 6 curas y 2 clérigos rasos); 3 ) y una familia de seglares, fámulos, con un criado mayor casado, tres pajes (hermanos), dos ayudas de cámara casados y otro soltero, un sirviente de los criados, un veedor soltero, un repostero y un mozo de repostero solteros, un cocinero, un mozo de cocina, un sangrador de la familia, un portero, dos lacayos solteros, un cochero mayor casado, un cochero delantero soltero y un mozo de mulas soltero (total 20) ${ }^{153}$. Por su parte, el canónigo y arcediano de

150 Vizuete Mendoza, J. C.: "Las monjas del monasterio cisterciense de San Clemente de Toledo según el Libro de los Recibimientos y Profesiones (1574-1835)", Anuario Jurídico y Económico Escurialense, LIV, (2021), pp. 501-526, punto 3.3 .

151 Una vez más son los casos bien conocidos por nosotros. Jerónimo de Ceballos tenía en su casa al que llegó a ser el licenciado Miguel García, y que actuó de mayordomo de su casa, de capellán y después de fiel albacea testamentario (Jerónimo de Ceballos..., op. cit. (nota 61), p. 107). Algo parecido, pero a mayor escala, ocurrió en la casa del doctor Pisa, de donde salió para vestir sotana Diego García Ballesteros, o el hijo de albañil Simón de Haro, quien se doctoró y fue beneficiado - en el doble sentido de la palabra- con una capellanía en el beaterio de San Pedro ad Vincula (más tarde constituida en memorias de su patrocinador), después de un curado en Villanueva de la Cañada y por último del curato de la parroquia toledana de San Lorenzo, o los licenciados Cortés, Francisco Díaz, Canisio y el doctor Juan Rojas, que fueron también patrocinados por el capellán mozárabe...

152 Archivo Histórico Provincial de Toledo, Hacienda, libros 33063, 33067/2, 33068, 33069.

153 Ibidem, libro H33063, ff. 1-5, 30/08/1753. Tal era el volumen de esta familia decanal que se necesitaban dos casas para albergarla, cuyo arrendamiento costaba 2.000 (principal) y 1.000 (accesoria) reales anuales. También 
Madrid, Manuel Guzmán el Bueno tenía 25 personas a su alrededor, entre un ama de llaves, una criada mayor viuda, otra criada para el cuidado de la ropa, una antigua y dos jubiladas/enfermas de entre 44 y 52 años; y un capellán-mayordomo, un oficial de secretaría, un paje, un ayuda de cámara, un administrador de rentas (el que más cobraba, 4.400 reales al año, con 33 años de edad), un mayordomo para la casa de Madrid "para los viajes", un portero, un cocinero mayor, un ayudante de cocina, un lacayo jubilado (32 años), dos lacayos jóvenes, un cochero mayor (de 40), otro delantero, un mozo de mulas, un jardinero de 64 años para su finca de recreo ("que su señoría tiene en arriendo para su diversión", con su mujer, que hacía de lavandera), dos guardas de soto para la misma y un ayudante de guarda (el más joven, de 17 años) ${ }^{154}$. En el extremo más modesto, el más usual, estaba el presbítero licenciado José Atanasio García de Escalona, inquisidor decano del Santo Oficio de Toledo, cuya familia se componía de un sobrino de 14 años, un ama de 52, un paje ordenado de menores, y una criada de 28 , otra de 21 y un lacayo de $54^{155}$; o el capellán mayor de la Capilla de San José, Alonso Fernández de Madrid, que estaba rodeado por tres criadas de 24, 23 y 19 años y un criado de 20 ${ }^{156}$; o el presbítero Diego Caballero de Arteaga, cura propio de la parroquia de Santa María Magdalena, que convivía con dos primas hermanas solteras cuarentonas y un criado y una criada veinteañeros solteros, así como José Clavijo, cura de Santa Leocadia, que tenía con él a su madre de 77 y a un hermano de 49 años ${ }^{157}$. En fin, que, como vemos, difícilmente podríamos aplicar los coeficientes de conversión de vecinos usuales utilizados en las familias seglares para las eclesiásticas.

Relaciones laico-eclesiásticas. Por lo demás, cabe también reflexionar sobre las relaciones eclesiástico-civiles en el seno de la ciudad, sagrada e imperial a un tiempo según la propia divulgación de sus grandezas. Los poderes religioso y seglar se mostraban en complemento, cuando no en competencia continua, generando continuos roces jurisdiccionales. No obstante, y sin llegar la sangre al río del pleito ante la maraña de tribunales, eclesiásticos y reales, lo normal es que dichos conflictos se canalizaran mediante la observación escrupulosa del protocolo en todos aquellos actos en donde confluyeran ambos poderes, que eran prácticamente todos los que tenían lugar en el escenario urbano, en donde se seguía un singular emparejamiento de instituciones ${ }^{158}$. El arzobispo primado no tenía par, salvo el rey de Castilla, de España; pero relativamente escasas eran sus apariciones en el escenario público toledano. Los que coincidían con cierta profusión eran el Cabildo Primado y el Ayuntamiento de la Ciudad, con su deán y su corregidor a la cabeza, respectivamente; y en estas confluencias podían encontrarse con la nobleza más granada de titulados en sus

se especifican los sueldos que cobraban todos ellos (sus rendimientos de trabajo) que venían expresados en dinero (ración diaria y sueldo anual), manutención alimenticia, ropa de vestir y ayuda de alojamiento, habiendo graduación según la importancia de la función doméstica desempeñada y de su estado civil (los casados percibían un tercio más para mantener a su propia familia y, en su caso, los viudos tenían una especie de jubilación). No obstante, muchos de los criados solo "tienen cuanto necesitan".

154 Ibidem, ff. 6-7v. En total, rentaban (costaban) los criados la bonita suma de 66.357 reales anuales.

155 Ibidem, ff. 132.

156 Ibidem, ff. 76. Como era usual, a esa capellanía en la parroquia de San Nicolás añadía otras tres: una en la de San Salvador, un patronato de legos y memoria de misas en la de San Juan Bautista y otra capellanía en el convento franciscano tercero de San Juan de la Penitencia.

157 Ibidem, f. 323 y 373.

158 Como vimos en el escrito de Sánchez de Soria, J.: Toledo..., op. cit.; también en el capítulo 6 de nuestro trabajo Poder y poderes en la ciudad de Toledo..., op. cit. 
dignidades o en el regimiento. En todo caso, la mayoría de esas ocasiones eran precisamente actos religiosos: ceremonias (misas) en la catedral o en iglesias señaladas (fiestas del año litúrgico, canonizaciones, patrones, tedeums, rogativas), procesiones (con el Corpus a la cabeza ${ }^{159}$ ), incluso autos de fe... Tampoco faltaban algunas celebraciones en donde clero y ciudad tenían sus lugares reservados en los mejores sitios: representaciones teatrales (con acompañamiento de música), jolgorios, corridas de toros, juegos de cañas o certámenes literarios. La cuestión era siempre visibilizar lo suficiente el poder religioso en todas sus dimensiones en el teatro sociopolítico urbano. Por otro lado, de lo que no había duda alguna era de la primacía de la iglesia toledana, en la caridad, en la beneficencia o auxilio social, en el sistema hospitalario, por demás, en donde los poderes seculares sólo podían mostrarse solícitos en la colaboración ${ }^{160}$. No hace falta insistir de nuevo en la preponderancia eclesiástica en el campo de la seguridad social, en tres aspectos: en el reparto extraordinario de víveres en épocas de escasez y penuria; en el patrocinio de hospitales; y en la dotación tanto de mujeres para casarse como de pensiones para clérigos jubilados. En el caso toledano el Arzobispo junto con la Catedral patrocinó varios importantes hospitales, igualmente en su fundación como en su sostenimiento e incluso gobierno. Son los casos del Hospital de Dementes o del Nuncio, por su fundador el canónigo Francisco Ortiz, único en su género; el Hospital de Santa Cruz, fundación del cardenal Mendoza, para expósitos ${ }^{161}$; o el Hospital de San Bautista o de Afuera, para varios géneros de enfermedad y una impresionante farmacopea.

Para terminar, el mundo de la cultura escrita (archivos y bibliotecas) sigue teniendo una relación privilegiada con el clero, en la Edad Media como en mayor medida en la Moderna. Y tenemos que seguir hablando de una vinculación especial del mecenazgo codicológico con el ámbito catedralicio ${ }^{162}$, a lo que habría que añadir tantas y tantas bibliotecas presbiterales (sobre todo de canónigos), y hasta la fundación de una Biblioteca Arzobispal en el siglo XVIII (1773) ${ }^{163}$, que complementó la Biblioteca Capitular de la Catedral de Toledo. De la riqueza y el entusiasmo bibliográficos del cabildo capitular han quedado multitud de muestras ${ }^{164}$, y desde luego

159 Sobre este particular v. Fernández Juárez, G., Martínez Gil, F. (Coords.): La fiesta del Corpus Christi, Cuenca, Ediciones de la UCLM, 2002.

160 Rodríguez de Gracia, H., Pobreza y beneficencia..., op. cit. (nota 127); Martz, L.: Poverty and Welfare in Habsburg Spain. The Example of Toledo, Cambridge University Press, 1983.

${ }_{161}$ El trabajo de Rodríguez González, A.: El abandono de niños en la España moderna, Tesis doctoral, Universidad de Castilla-La Mancha, 2003, se centra exhaustivamente en este también singular hospital.

162 Rodríguez Díaz, E.: "El patronazgo eclesiástico, los libros y la escritura en la Baja Edad Media Castellana", en Marchant Rivera, A. y Barco Cebrián, L.: Escritura y sociedad: el clero, Granada, Comares, 2017, pp. 36-64. Para el siglo XV arroja cifras de mecenazgo individual del clero secular que alcanzan un $95 \%$, mientras que las del clero regular es muy pequeña: esto es, que la Escuela Catedralicia y sus dignidades y canónigos han ido arrebatando protagonismo bibliófilo a los monasterios y conventos, sobre todo en libros de lujo o aparato y de buena factura.

163 El famoso fondo Borbón-Lorenzana que, junto a incautaciones de los jesuitas y fondos desamortizados de diferentes conventos, con sus impresos y manuscritos, fue incautado por el Estado en 1940 y que tras varios acuerdos con el Arzobispado hoy constituye el Fondo Antiguo de la Biblioteca Regional de Castilla-La Mancha en el Alcázar de Toledo. V. Martínez Gil, F. (coord.): El Alcázar de Toledo: Palacio y Biblioteca. Un proyecto cultural para el siglo XXI, Toledo, JCCLM, 1998, parte segunda.

164 Sánchez González, R.: "La cultura de las letras en el clero capitular de la catedral toledana”, en Aranda Pérez, F. J.: Sociedad y élites eclesiásticas en la España moderna, Cuenca, Ediciones de la UCLM, 2000, pp. 163-236; que sirvió de pórtico a la monografía del mismo autor Iglesia y sociedad en la Castilla moderna. El Cabildo catedralicio de la Sede Primada (siglo XVII), Cuenca, Ediciones de la Universidad de Castilla-La Mancha, 
este acervo es fundamental para el cabal conocimiento de la cultura escrita hispánica moderna; en el coleccionismo, en la producción material de los libros (impresos, pero también manuscritos) y, por supuesto en las temáticas, en los capítulos tradicionales del Derecho, la Religión, la Historia, la Geografía y la Biografía, la Literatura (latina, romance), y las ciencias (sociales, sanitarias, gastronómicas, militares, musicales...). Sin duda, el mundo del libro en Toledo seguía escribiéndose de la mano de sus clérigos... y hasta de sus monjas, desde una madre Teresa de Jesús hasta sor Teresa Jesús María, sor María de Santa Isabel y muchas más ${ }^{165}$.

\section{Bibliografía}

Alcocer, P.: Hystoria, o descripción de la Imperial Cibdad de Toledo..., Toledo, Juan Ferrer, 1554.

Alguacil Martín, E., Domínguez Montero, D.: “Doménico Theotocópuli, Andrés Núñez de Madrid y el pleito por la pintura de El Entierro del señor de Orgaz: un proceso judicial inédito en el Archivo Diocesano de Toledo", Cuadernos de Archivo Secreto, 1, (2019).

Aranda Pérez, F. J.: Poder y poderes en la ciudad de Toledo. Gobierno, sociedad y oligarquías en la Edad Moderna, Cuenca, Ediciones de la UCLM, 1999.

Aranda Pérez, F. J.: "El clero parroquial también se acabilda. El Cabildo de Curas y Beneficiados de Toledo", en Aranda Pérez, F. J. (Coord.): Sociedad y elites eclesiásticas en la España Moderna, Cuenca, Ediciones de la Universidad de Castilla-La Mancha, 2000, pp. 237-287.

Aranda Pérez, F. J.: Jerónimo de Ceballos: un hombre grave para la república. Vida y obra de un hidalgo del saber en la España del Siglo de Oro, Córdoba, Servicio de Publicaciones Universidad de Córdoba, 2001.

Aranda Pérez, F. J., Sánchez González, R.: “Jurisprudencia y bibliofilia. La familia y la biblioteca de los Narbona”, en Aranda Pérez, F. J.: Letrados, juristas y burócratas en la España moderna, Cuenca, Ediciones de la UCLM, 2005, pp. 253-396.

Aranda Pérez, F. J.: "Símbolos de autoridad y poder ciudadanos en el mundo hispánico moderno: la confrontación historiográfica toledano-hispalense", en Revista de Historiografía (Instituto Julio Caro Baroja-UC3M), 16 (Monográfico La ciudad y la construcción de la modernidad. Identidades urbanas y mitologías ciudadanas (siglos XVI-XIX), IX, (1/2012), pp. 164-178.

Aranda Pérez, F. J.: "El influjo complutense, de Cisneros y Fonseca a Carranza", en García Pinilla, I. J. (Coordinador), Disidencia religiosa en Castilla la Nueva en el siglo XVI, Toledo, Almud, 2013, pp. 29-57.

2000, en donde en el apéndice aparece la biblioteca abundosa del canónigo magistral doctor Gregorio Barreiro, administrador del hospital de Santa Cruz de Toledo, por cierto, de 1.540 títulos y 1.990 volúmenes (1641), que adquirió gran parte de la biblioteca del canónigo penitenciario doctor Pedro Salazar de Mendoza (cit. supra, administrador del Hospital de San Juan Bautista o de Tavera), que dejó 1.304 títulos (1629. También la de los Narbona en Aranda Pérez, F. J., Sánchez González, R.: "Jurisprudencia y bibliofilia. La familia y la biblioteca de los Narbona", en Aranda Pérez, F. J.: Letrados, juristas y burócratas en la España moderna, Cuenca, Ediciones de la UCLM, 2005, pp. 253-396, con 1.632 títulos (2.061 volúmenes) impresos más 150 manuscritos entre legajos, cuadernos y libros (1679).

165 V. Baranda Leturio, N., Marín Pina, M. C. (eds.): Letras en la celda. Cultura escrita de los conventos femeninos en la España moderna, Madrid, Iberoamericana-Vervuert, 2014; Lewandowska, J.: Escritoras monjas. Autoridad y autoría en la escritura conventual femenina de los Siglos de Oro, Madrid, Iberoamericana-Vervuert, 2019. 
Aranda Pérez, F. J.: "Memoria y fortuna de Cisneros: entre la postergación y el mito", en Cisneros 1517-2017. Arquetipo de Virtudes, Espejo de Prelados, Catedral Primada de Toledo, Antonio Pareja Editor, Toledo 2017, pp. 55-67.

Aranda Pérez, F. J.: "Castile, crown of oligarchic republics. Visions and interpretactions of the urban in Early Modern Spain (16 ${ }^{\text {th }}$ to $17^{\text {th }}$ century)", en Fray, J.-L., Pauly, M., Pinheiro, M., Sheutz, M. (Ed.): Urban spaces and the complexity of cities, Böhlau Verlag, Köln 2018, pp. 233-243 + 8 figs. in appendix.

Aranda Pérez, F. J.: "El Greco "famoso pintor", y los intelectuales cristianopolitanos de Toledo. (A propósito de sus retratos letrados", en Tiempos Modernos, 37, (2018/2), pp. 187-220.

Aranda Pérez, F. J.: “Un reino de repúblicas encantadas. Una reflexión desde Toledo sobre las invenciones ciudadanas españolas (siglos XVI y XVII)", en Bénat-Tachot, L., Blanco, M., Guillaume-Alonso, A., Thieulin-Pardo, H. (Dir.): L'invention de la ville dans le monde hispanique (XI ${ }^{e}-X V I I I^{e}$ siècles), Paris, Editions Hispaniques, Université Paris-Sorbonne, 2019, pp. 255-281 + 3 ilus.

Aranda Pérez, F. J.: Toledo circa 1605. La historia-descripción cristianopolitana de Francisco de Pisa, (prólogo de Fernando Marías Franco), Toledo-Cuenca, Bibliotheca Argentea, Ediciones de la UCLM-Antonio Pareja Editor S. L., Toledo 2021.

Baranda Leturio, N., Marín Pina, M. C. (eds.): Letras en la celda. Cultura escrita de los conventos femeninos en la España moderna, Madrid, Iberoamericana-Vervuert, 2014.

Barrio Gozalo, M.: "El bajo clero en la España del siglo XVIII. Estado de la cuestión, problemas y direcciones de la investigación actual", Coloquio Internacional Carlos III y su siglo, Madrid, UCM, 1990, tomo I, pp. 793-805.

Barrio Gozalo, M.: El clero en la España Moderna, Madrid-Córdoba, CSIC-CajaSur, 2010.

Barrio Gozalo, M.: "Rentas de los obispos españoles y pensiones que las gravan en el Antiguo Régimen (1556-1834)", Revista de Historia Moderna, 32, (2014), pp. 219-244.

Bizzocchi, R.: Généalogies fabuleuses. Inventer et faire croire dans l'Europe moderne, Paris, Éditions Rue d'Ulm/Presses de l'École normales supérieure, 2010.

Bunes Ibarra, M. A. de, Alonso Acero, B. (Coords.): Orán. Historia de la Corte Chica, Madrid, Polifemo, 2011.

Candau Chacón, M. L.: La carrera eclesiástica en el siglo XVIII. Modelos, cauces y formas de promoción en la Sevilla rural, Universidad de Sevilla, 1993.

Castejón y Fonseca, D. de: Primacía de la Santa Iglesia de Toledo, su origen, sus medras, sus progresos... defendidas contra las impugnaciones de Braga, Madrid, Diego Díaz de la Carrera, 1645.

Cerrillo Cruz, G.: “Aproximación al estatuto jurídico de los familiares de la Inquisición española", Manuscrits, 17, (1999), pp. 141-158.

Cruz Palomino, L. de la: "Censo de cofradías de la Ciudad de Toledo del año 1773", Archivo Secreto, 2, (2004), pp. 316-325.

Colomina Torner, J., Arellano García, M.: Catálogo del Archivo de la Capilla de Reyes en la Catedral de Toledo, Toledo, Cabildo Primado, 2015.

Esteneaga y Echevarría, N.: El Cardenal Aragón (1626-1677), París, Imprentas E. Desfossés, 1929, 2 tomos.

Dedieu, J.-P.: L'administration de la foi. L'Inquisition de Tolède (XVI $\left.-X V I I I^{e}\right)$, Madrid, Casa de Velázquez, 1989.

Díaz Rodríguez, A. J.: El clero catedralicio en la España moderna: los miembros del Cabildo de la Catedral de Córdoba (1475-1808), Universidad de Murcia, 2012.

Díaz Rodríguez, A. J.: "Purity of Blood and the Curial Market in Iberian Cathedrals." eHumanista/Conversos, 4, (2016), pp. 38-63. 
Díez del Corral Garnica, R.: Arquitectura y mecenazgo. La imagen de Toledo en el Renacimiento, Madrid, Alianza, 1987.

Dionisio Vivas, M. Á.: "El Archivo Diocesano de Toledo. Hacia una descripción de sus fondos", Toletana, 24, (2011), pp. 159-195.

Domínguez Ortiz, A.: Los judeoconversos en la España moderna, Madrid, Mapfre, 1993.

Donézar Díez de Ulzurrun, J. M.: Riqueza y Propiedad en la Castilla del Antiguo Régimen. La provincia de Toledo en el siglo XVIII, Madrid, Instituto de Estudios Agrarios, Pesqueros y Alimentarios, 1984.

Dubert, I.: "La domesticación, la homogeneización y la asimilación de las conductas del clero gallego del Antiguo Régimen a la idealidad del modelo tridentino, 1600-1850", en El Antiguo Régimen y la Revolución Liberal. Homenaje a Miguel Artola, Madrid, UAM, 1995, vol. 2, pp. 396-477.

Fernández Collado, Á.: Concilios Toledanos Postridentinos. Estudio y edición, Toledo, Diputación Provincial, 1996.

Fernández Collado, Á.: Obispos de la Provincia de Toledo (1500-2000), Toledo, Estudio Teológico de San Ildefonso, 2000.

Fernández Collado, Á.: Historia de la Iglesia en España. Edad Moderna, Toledo, Instituto Teológico San Ildefonso, 2007.

Fernández Collado, Á.: Los informes de Visita ad limina de los arzobispos de Toledo (16031917), Toledo, Cabildo Primado-ITSI-Diputación Provincial, 2015.

Fernández Collado, Á.: La Catedral de Toledo en el siglo XVI. Vida, arte y personas, Toledo, Cabildo Primado, 2015².

Fernández Collado, Á.: Los Arzobispos de Toledo en la Edad Moderna y Contemporánea. Episcopologio toledano, Toledo, Cabildo Primado, 2017.

Fernández Juárez, G., Martínez Gil, F. (Coords.): La fiesta del Corpus Christi, Cuenca, Ediciones de la UCLM, 2002.

Fernández Terricabras, I.: Felipe II y el clero secular. La aplicación del concilio de Trento, Madrid, Sociedad Estatal para la Conmemoración de los Centenarios de Felipe II y Carlos $\mathrm{V}, 2000$.

Franco Mata, Á.: "El coro de la catedral de Toledo", Abrente, 42-43, (2010-2011), pp. 113165.

Franco Mata, Á.: Las Capillas de la Catedral de Toledo. Historia, liturgia y arte, Toledo, Cabildo Primado, 2018.

García Oro, J.: La Iglesia de Toledo en tiempo del Cardenal Cisneros (1495-1516), Toledo, Estudio Teológico de San Ildefonso, 1992.

García Oro, J.: El cardenal Cisneros. Vida y empresas, Madrid, BAC, 1993.

Gómez Navarro, S.: Iglesia parroquial y medio rural en el Antiguo Régimen. Nuestra Señora de la Asunción de Palma del Río (Córdoba), Madrid, Polifemo, 2020.

Gómez Vozmediano, M. F., Sánchez González, R.: "Pedro Salazar de Mendoza (1549-1629): cronista nobiliario y bruñidor de linajes", Tiempos Modernos, 8, 31, (2015), pp. 393-422.

González Cuenca, J.: Toledo, la contemplada. Cosas notables que tiene la Imperial Ciudad de Toledo (Romance y Memorial), Toledo, (en prensa).

Gonzálvez Ruiz, R. (coord..): La Catedral Primada de Toledo: dieciocho siglos de historia, Toledo, Promecal, 2010.

Goñi Gaztambide, J.: Historia de la Bula de Cruzada en España, Vitoria, Victoriensia-Seminario, 1958.

Gutiérrez García-Brazales, M.: "El Consejo de la Gobernación del Arzobispado de Toledo", Anales Toledanos, XVI, (1983), pp. 63-95; y XXV (1988), pp. 109-140. 
Gutiérrez García-Brazales, M.: "La Audiencia Arzobispal de Toledo", La administración de justicia en la Historia de España, Guadalajara, Junta de Comunidades de Castilla-La Mancha, 1999, pp. 611-628.

Herrera Vaca, F. de: Urbs, et Roma hispanica sive praeexcellentia, et magnitudine Toletanae urbis cum magnitudine, et praexcellentia urbis Romanae conferanda, Toledo, Franciscus Calvo, 1664.

Herzog, T.: Vecinos y extranjeros. Hacerse español en la Edad Moderna, Madrid, Alianza, 2006.

Iglesia y religiosidad en España. (Actas de las V Jornadas de Castilla-La Mancha sobre investigación en archivos), Guadalajara, Junta de Comunidades de Castilla-La Mancha, Anabad Castilla-La Mancha, Asociación de Amigos del Archivo Histórico Provincial de Guadalajara, 2002, 3 vols.

Jaime Valor, S.: "Las relaciones entre el Cabildo catedralicio de Toledo y la nobleza a través de las actas capitulares del setecientos", en Fortea Pérez, J. I., Gelabert, J. E., López Vela, R., Postigo Castellanos, E. (coords.): Monarquías en conflicto. Linajes y noblezas en la articulación de la Monarquía Hispánica, Santander, FEHM, 2018, pp. 1145-1155.

Jiménez de Gregorio, F.: Azután, una villa de señorio monástico femenino. (Del siglo XII al año 1839), Toledo, IPIET, 1990.

Kagan, R. L.: "Pedro de Salazar de Mendoza as Collector, Scholar and Patron of El Greco", Studies in the History of Art (El Greco, Italy and Spain), 13, (1984), pp. 85-92.

Kagan, R. L.: "Contando vecinos: el censo toledano de 1569", Studia Historica. Historia Moderna, XII, (1994), pp. 115-135.

Lewandowska, J.: Escritoras monjas. Autoridad y autoría en la escritura conventual femenina de los Siglos de Oro, Madrid, Iberoamericana-Vervuert, 2019.

Loaysa Girón, G. de: Collectio Conciliorum Hispaniae, diligentia Garsiae Loaisa elaborata eiusque vigiliis aucta, Madriti, Petrus Madrigal, 1593.

Lop Otín, M. J.: El Cabildo Catedralicio de Toledo en el siglo XV. Aspectos institucionales y sociológicos, Madrid, Fundación Ramón Areces, 2003.

López Álvarez, A.: Poder, lujo y conflicto en la Corte de los Austrias. Coches, carrozas y sillas de manos, 1550-1700, Madrid, Polifemo, 2007.

López Gómez, O.: “Acogerse a sagrado: violencia, poder y recintos eclesiásticos a fines del medievo", en Vizuete Mendoza, J. C., Martín Sánchez, J. (coords.): Sacra loca toletana. Los espacios sagrados en Toledo, Cuenca, Ediciones de la UCLM, 2008, pp. 189-222.

López Vela, R.: "Historiografía y ciudad. El debate sobre el Toledo en el Humanismo y la época confesional", en López Vela, R. (Ed.), Ciudades, gentes e intercambios en la monarquía hispánica en la Edad Moderna, Santander, Ediciones Universidad de Cantabria, 2019, pp. 133-194.

Lozano, C.: Los Reyes Nuevos de Toledo, Madrid, Imprenta Real, 1677.

Marchán Rivera, A., Barco Cebrián, L.: Escritura y sociedad: el clero, Granada, Comares, 2017.

Marías Franco, F.: La Arquitectura del Renacimiento en Toledo (1541-1631), Toledo-Madrid, CSIC, 1983-86.

Marías Franco, F.: El Greco. Biografía de un pintor extravagante, Madrid, Nerea, 1997.

Marías Franco, F.: El hospital de Tavera de Toledo, Sevilla, Fundación Casa Ducal de Medinaceli, 2007.

Martín López, D.: Orígenes y evolución de la Universidad de Toledo (1485-1625), Toledo, Ediciones Parlamentarias de Castilla-La Mancha, 2006. 
Martínez Gil, F.: Toledo y la crisis de Castilla, 1677-1686, Toledo, Ayuntamiento, 1987.

Martínez Gil, F. (coord.): El Alcázar de Toledo: Palacio y Biblioteca. Un proyecto cultural para el siglo XXI, Toledo, JCCLM, 1998.

Martínez Gil, F.: "De civitas regia a civitas dei. El imaginario histórico de Toledo en los siglos XVI y XVII", en Vizuete Mendoza, J. C., Martín Sánchez, J. (coords.): Sacra loca toletana. Los espacios sagrados en Toledo, Cuenca, Ediciones de la UCLM, 2008, pp. 319-367.

Martínez Gil, F.: La invención de Toledo. Imágenes históricas de una identidad urbana, Ciudad Real, Almud, 2007.

Martínez Martínez, J. A.: “Construyendo la memoria y la eternidad: las capillas, capellanías, ermitas y obras pías de la familia Muñoz de Otálora (siglos XVI-XVIII), Tiempos Modernos, 42, (2021), pp. 72-92.

Martínez Ruiz, E. (dir.): El peso de la Iglesia. Cuatro siglos de órdenes religiosas en España, Madrid, Actas, 2004.

Martz, L., Porres Martín-Cleto, J.: Toledo y los toledanos en 1561, Toledo, Instituto Provincial de Investigaciones y Estudios Toledanos, 1974.

Martz, L.: Poverty and Welfare in Habsburg Spain. The Example of Toledo, Cambridge University Press, 1983.

Martz, L.: A network of converso families in Early Modern Toledo. Assimilating a Minority, Ann Arbor, University of Michigan Press, 2003.

Millán Martínez, J. M., Martínez Soria, C. J. (Coords.): Diego Ramírez de Villaescusa: obispo y mecenas, Cuenca, Ediciones de la UCLM, 2009.

Montemayor, Julian: Tolède, entre fortune et déclin (1530-1640), Limoges, PULIM, 1996.

Morgado García, A.: "Curas y parroquias en la diócesis de Cádiz (1700-1834)", Obradoiro de Historia Moderna, 22, (2013), pp. 207-230.

Moxó, S. de: Los antiguos señorios de Toledo. Evolución de las estructuras jurisdiccionales en la comarca toledana desde la Baja Edad Media hasta fines del Antiguo Régimen, Toledo, IPIET, 1973.

Negredo del Cerro, F.: Los predicadores de Felipe IV. Corte, intrigas y religión en la España del Siglo de Oro, Madrid, Actas, 2006.

Orozco Pardo, J. L.: Christianópolis. Urbanismo y Contrarreforma en la Granada del 600, Granada, Diputación Provincial, 1985.

Ortega Gómez, L.: Los familiares del Santo Oficio en el mundo rural de los tribunales de Toledo y Cuenca (Ss. XVI-XVIII), Cuenca, Ediciones de la UCLM, 2021.

Ortiz, B.: La Catedral de Toledo 1549 según el doctor Blas Ortiz. Descripcion Graphica y Elegantissima de la S. Iglesia de Toledo, estudios de Gonzálvez, R. y Pereda, F., Toledo, Antonio Pareja Editor, 1999.

Lozano Parreño y Navarro, A.: Compendio histórico-cronológico-geográfico en que se explica el número de dignidades, canonicatos, raciones, medias raciones y beneficios de todas las iglesias metropolitanas y catedrales de España..., Madrid, Antonio Pérez de Soto, 1756.

Palomo, F.: Monográfico "La memoria del mundo: clero, erudición y cultura escrita en el mundo ibérico (siglos XVI-XVIII)", Cuadernos de Historia Moderna (UCM). Anejos, XIII (2014).

Pérez, J.: Cisneros, el cardenal de España, Madrid, Taurus, 2014.

Pérez García, R. M.: "Dominicos, conversos y limpieza de sangre en España. Siglos XVXVI", eHumanista/Conversos, 5, (2017), pp. 167-191.

Pisa, F. de: Descripción de la Imperial Ciudad de Toledo..., Toledo, Pedro Rodríguez, 1605. (Facsímil, Toledo, IPIET, 1974). 
Pizarro Llorente, H.: Un gran patrón en la Corte de Felipe II: don Gaspar de Quiroga, Madrid, Universidad Pontificia Comillas, 2004.

Pizarro Llorente, H.: "Los miembros del Cabildo de la Catedral de Toledo durante el arzobispado de Gaspar de Quiroga (1577-1594)”, Hispania Sacra, LXII, 126, (2010), pp. 563-619.

Quintanadueñas, A. de: Santos de la Imperial Ciudad de Toledo y su arçobispado, excelencias que goça su Santa Iglesia, fiestas que celebra su ilustre clero, Madrid, Pablo del Val, 1651.

Ramírez de Arellano, R.: Las parroquias de Toledo, Toledo, IPIET, 1997 (reimpresión de 1921).

Rey Castelao, O.: El Voto de Santiago en la España Moderna, Santiago de Compostela, Universidad, 1984.

Rivera Recio, J. F.: El Arzobispo de Toledo don Bernardo de Cluny (1085-1124), Roma, Iglesia Nacional Española, 1962.

Rivera Recio, J. F.: Los Arzobispos de Toledo en la Baja Edad Media (s. XII-XV), Toledo, Diputación Provincial, 1969.

Rivera Recio, J. F.: Los Arzobispos de Toledo. Desde sus orígenes a finales del siglo XI, Toledo, Diputación Provincial, 1973.

Rodríguez González, A., Sánchez Gamero, J. P.: "Información sobre cofradías toledanas en el Archivo Diocesano de Toledo", Archivo Secreto, 2, (2004), pp. 328-343.

Rodríguez González, A.: Los primados de Toledo, 1666-1709, Toledo, Ediciones Parlamentarias de Castilla-La Mancha, 2006.

Rodríguez González, A.: "Itinerarios sagrados en el Toledo de la Edad Moderna", en Vizuete Mendoza, J. C., Martín Sánchez, J. (coords.): Sacra loca toletana. Los espacios sagrados en Toledo, Cuenca, Ediciones de la UCLM, 2008, pp. 369-398.

Rodríguez González, A., Fernández Collado, A., Casteñeda Tordera, I.: Catálogo del Archivo de la Capilla de San Pedro, Toledo, Instituto Teológico San Ildefonso, 2007.

Rodríguez de Gracia, H.: Pobreza y beneficencia en la provincia (1500-1800), Toledo, Instituto Provincial de Estudios Toledanos, 1983.

Rodríguez de Gracia, H.: El Hospital del Rey de Toledo. Contribución a la historia de un hospital toledano, Toledo, INSS, 1985.

Rodríguez de Gracia, H.: El crepúsculo patrimonial de Toledo, Toledo, Ayuntamiento, 1999.

Rodríguez de Gracia, H.: "La visita eclesiástica en el arzobispado de Toledo. Conforme a las Instrucciones de los arzobispos Alberto de Austria y García de Loaysa", Toletana. Cuestiones de Teología e Historia, 8, (2003), pp. 149-197.

Rodríguez de Gracia, H.: El rostro de un confeso: Andrés Núñez de Madrid, párroco de Santo Tomé (1562-1601), Ediciones Puertollano, 2017.

Rodríguez de Gracia, H.: “'Macula infamiae' en los expedientes de limpieza de la Catedral de Toledo (1577-1623), Historia y Geneaología, 7, (2017), pp. 147-188.

Rodríguez de Gracia, H.: "Nepotes y limpieza de sangre en la Catedral de Toledo", Historia y Genealogía, 9, (2019), pp. 145-178.

Rodríguez López-Brea, C. M.: Don Luis de Borbón, el cardenal de los liberales (1777-1823), Toledo, Junta de Comunidades de Castilla-La Mancha, 2002.

Rodríguez Solís, J. J.: “La Monarquía de España desde Castilla. Identidad y reinos en la obra de Pedro Salazar de Mendoza", Espacio, Tiempo y Forma. Historia Moderna, 30, (2017), pp. 335-360.

Rubial García, A.: "Iconos vivientes y sabrosos huesos. El papel de los obispos en la construcción del capital simbólico de la episcópolis de la Nueva España (1610-1730)”, Mar- 
tínez López Cano, M. P., Cervantes Bello, F. J. (coords.): Expresiones y estrategias. La Iglesia en el orden social novohispano, México, UNAM et alii, 2017, pp. 217-266.

Sáez, R.: "Le clergé des paroisses de Tolède à la fin du XVI" siècle (posibilites et limites d'une recherche", en Tolède et l'expansion urbaine en Espagne (1450-1650), Madrid, Casa de Velázquez, 1991, pp. 205-224.

Sáez Olivares, A.: El obispo Diego Ramírez de Villaescusa y su papel como mecenas de las artes, Madrid, Dykinson, 2021.

Sánchez González, R.: "La cultura de las letras en el clero capitular de la catedral toledana", en Aranda Pérez, F. J.: Sociedad y élites eclesiásticas en la España moderna, Cuenca, Ediciones de la UCLM, 2000, pp. 163-236.

Sánchez González, R.: Iglesia y sociedad en la Castilla moderna. El Cabildo catedralicio de la Sede Primada (siglo XVII), Cuenca, Ediciones de la Universidad de Castilla-La Mancha, 2000.

Sánchez de Soria, J.: Toledo. Su prudente gobierno y las corteses ceremonias con que lo ejerce, introducción, transcripción y notas de M. García Ruipérez, Toledo, Ayuntamiento, 2004.

Santaolaya Heredero, L.: Una ciudad del Antiguo Régimen: Toledo en el siglo XVIII. (Personas, propiedad, administración), Madrid, UNED, 1991.

Serrano Rodríguez, E., Gómez Vozmediano, M. F.: "Imprenta, dinero y fe: la impresión de bulas en el convento dominico de San Pedro Mártir de Toledo (1483-1600)", Tiempos Modernos, 27, (2013/2), pp. 1-65.

Sicroff, A. A.: Los estatutos de limpieza de sangre. Controversias entre los siglos XV y XVII, Madrid, Taurus, 1985.

Tellechea Idígoras, J. I.: Fray Bartolomé de Carranza. Documentos históricos, Madrid, RAH, 1962-1994.

Viñas Mey, C y Paz, R.: Relaciones histórico-geográfico-estadísticas de los pueblos de España hechas por iniciativa de Felipe II: Reino de Toledo, Madrid, Instituto Balmes de Sociología-Instituto Juan Sebastián el Cano de Geografía-CSIC, 1963.

Vilar Berrogain, J.: "Conciencia nacional y conciencia económica, datos sobre la vida y la obra de Sancho de Moncada", estudio preliminar de la edición de Moncada, S. de, Restauración política de España, Madrid, Instituto de Estudios Fiscales, 1974.

Villaluenga de Gracia, S., Quesada Sánchez, F. J.: "Rentas, gastos y administración de la Obra y Fábrica de la Catedral de Toledo en la primera mitad del siglo XVI", Pecvnia, 1, (2005), pp. 201-227.

Vizuete Mendoza, J. C.: Azután en el Antiguo Régimen, Toledo, Caja Castilla-La Mancha, 1993.

Vizuete Mendoza, J. C.: "Lugares sagrados y órdenes religiosas. Monasterios y conventos de Toledo”, en Vizuete Mendoza, J. C., Martín Sánchez, J. (coords.): Sacra loca toletana. Los espacios sagrados en Toledo, Cuenca, Ediciones de la UCLM, 2008, pp. 157-187.

Vizuete Mendoza, J. C.: "Las monjas del monasterio cisterciense de San Clemente de Toledo según el Libro de los Recibimientos y Profesiones (1574-1835)", Anuario Jurídico y Económico Escurialense, LIV, (2021), pp. 501-526.

V. V. A. A.: La Vega Baja de Toledo, Toledo, Toletum Visigodo, 2009.

Zamorano Rodríguez, M. L.: Historia del Hospital de San Juan Bautista de Toledo en el siglo XVI, Madrid, Tesis de la UCM, 1992. 